\title{
Bond Covenants and Creditor Protection: Economics and Law, Theory and Practice, Substance and Process
}

William W. Bratton

Georgetown University Law Center, wwb@law.georgetown.edu

Georgetown Business, Economics and Regulatory Law Research Paper No. 902910

Copyright @ 2006 Cambridge University Press; http://journals.cambridge.org/action/ displayJournal?jid=EBR

This paper can be downloaded free of charge from:

https://scholarship.law.georgetown.edu/facpub/581

http://ssrn.com/abstract $=902910$

7 Eur. Bus. Org. L. Rev. 39-87 (2006)

This open-access article is brought to you by the Georgetown Law Library. Posted with permission of the author. Follow this and additional works at: https://scholarship.law.georgetown.edu/facpub 


\title{
Bond Covenants and Creditor Protection: Economics and Law, Theory and Practice, Substance and Process
}

\section{William W. Bratton*}

1. Introduction

2. The economic framework: conflicts of interest and costly contracting

2.1 Claim dilution

2.2 Asset withdrawal and underinvestment

2.3 Asset substitution and risky investment

2.4 Distress, prosperity, and the debt-equity conflict of interest

3. The full set of covenants

3.1 Affirmative and negative

3.2 Negative covenants

3.2.1 Restrictions on debt

3.2.2 Restrictions on prior claims

3.2.3 Restrictions on dividends and other payments to shareholders

3.2.4 Restrictions on mergers and sales of assets

3.2.5 Restrictions on investments

3.2.6 Early warning covenants

3.2.7 The prepayment alternative

3.3 Event risk

4. Business covenants in practice: risk, return, and market segment

4.1 Contracting practice and market segment

4.2 Covenants, risk, and return

4.3 Covenants, growth firms, and investment policy

4.4 Summary and analysis

5. Process barriers

5.1 Amendments and waivers

5.2 Payment terms, exchange offers, and unanimous action

5.3 Process reform in distress situations

5.4 Summary and analysis

6. Conclusion

\begin{abstract}
This article examines contractual protection of unsecured financial creditors in US credit markets. Borrowers and lenders in the United States contract against a minimal legal background that imposes the burden of protection on the lender. A working, constantly updated, set of contractual protections has emerged in response. But actual use of available contractual technology varies widely, depending on the level of risk and the institutional context. The credit markets sort borrowers according to the degree of the risk of financial distress, imposing substantial constraints only on the borrowers with the most dangerous incentives. At the same time, the contracting practice is sticky and lumpy, never quite managing to conform to the predictions of first generation agency theory. Levels of protection vary with institutional contexts. Exhaustive contracts providing something approaching complete protection against agency costs prove feasible only in relational contexts conducive to ongoing renegotiation over time due to small numbers of lenders operating under reputational constraints. The public bond markets do not hold out such a
\end{abstract}

* Professor of Law, Georgetown University Law Center. 
process context, and accordingly shut out the riskiest borrowers. The larger, less risky firms that do gain access to the bond markets borrow under contracts offering incomplete protection, with the level of protection roughly correlating to the borrower's risk level. This leaves bondholders confronting a residuum of agency costs and relying on secondary protections like monitoring, exit, diversification, and hedging. This has worked reasonably well in practice, subject to an historical exception concerning the risk of high-leverage restructuring. The bond markets searched for two decades for a stable solution to this problem, finally settling on across-the-board contractual protection only in recent years.

Keywords: agency costs, bank loans, bonds and bondholders, bond covenants, creditors' rights, legal capital, private placements, trust indentures.

\section{Introduction}

Creditor protection came into corporate law in the United States with the enactment of the first general corporation laws in the mid-nineteenth century. These extended limited liability to the shareholders as a usual consequence of incorporation, ${ }^{1}$ simultaneously imposing creditor protective provisions now known as the legal capital rules. The original legal capital rules mandated minimum capital, requiring that shareholders pay in full for stock issued and constraining their receipt of dividends and other distributions of capital. The rules made creditor protection as intrinsic an aspect of incorporation as limited liability. ${ }^{2}$ The judicial doctrine of disregarding the corporate fiction appeared during the same period, ${ }^{3}$ stemming from the related notion that the benefits of limited liability should apply only so long as a corporation conducted its business according to the legal model's basic requirements. The corporation, in short, had to maintain both formal integrity and fiscal responsibility. If it did not, the law reverted to the rule of individual responsibility and held the corporation's shareholders responsible for its debts.

Large corporations performing multiple tasks of production and marketing appeared around 1890. They rapidly came to dominate the American economy. Corporate law supported the new corporations, and changed in so doing. Charter competition appeared in 1888 when New Jersey created and marketed the first management-friendly corporate code. Diluted legal capital rules were a central part of the competitive package, and the other states quickly followed New Jersey's lead. As a practical matter, corporate creditors no longer received legal protection outside of insolvency. ${ }^{4}$

1 During the time of the special charter incorporation, corporate status did not inevitably imply limited liability, and charters did not contain creditor-protective provisions. See J.W. Hurst, The Legitimacy of the Business Corporation in the Law of the United States, 1780-1970 (Charlottesville, University Press of Virginia 1970) p. 51.

2 Ibid., at pp. 27-28, 51-52.

3 See Central Trust Co. v. Bridges, 57 F. 753, 766 (6th Cir. 1893), modified sub. nom. Central Trust Co. v. Condon, 67 F. 84 (6th Cir. 1895); Atchison, T. \& S.F.R.R. v. Davis, 34 Kan. 209, 210, 8 P. 530, 531 (1885); P. Blumberg, 'Limited Liability and Corporate Groups', 11 J. Corp. L. (1986) p. 573 at pp. 594, 609-611.

4 The incorporation statutes authorized low-par and no-par common stock, permitted minimal paidin capital and later reductions of capital, and dropped requirements for minimum debt-equity ratios. See Hurst, op. cit. n. 1, at p. 53. Legal capital rules persist in US corporate codes, in many cases retaining the same form taken in the nineteenth century. But the forms can be satisfied by a nominal fixed capital. As a practical result, the rules bar only against transfers made to shareholders of insolvent firms, tracking protection independently provided under fraudulent 
Financial creditors of large corporations took the changes in stride. The new firms' managers proved less likely to act against their creditors' interests than did entrepreneurial owner-managers of smaller corporations. They took a long-term, institutional view, investing with an eye to continuity and eschewing short-term gambles. ${ }^{5}$ The zone of common interests had limits, however. Lenders, rather than relying on it exclusively, developed new contractual protections. Mortgage indentures, in use since the $1830 \mathrm{~s}$, already facilitated secured debt financing for large capital projects, railroads most importantly, solving problems of enforcement and monitoring by widely dispersed bondholders. ${ }^{6}$ The debenture indenture appeared around 1900, just after the states diluted the legal capital rules, extending the indenture form to facilitate public sales of unsecured debt by large firms. The new indentures introduced the business covenant as a more flexible security device than the real property mortgage. ${ }^{7}$ With this innovation, long-term unsecured lending made sense for the first time in financial history.

The debenture indenture, used for public bond issues, continues to perform its original function in tandem with two close cousins developed later in the twentieth century, the note purchase agreement used in private placements of long-term debt securities ${ }^{8}$ and the term loan agreement used in long-term bank lending. Standard forms for these contracts have changed over time, developing reactively - as bond issuers have devised ways to evade covenants, bond lawyers have responded by filling in the gaps in the next generation of contracts. ${ }^{9}$ The mature 'full set' of covenants drawn on today appeared after World War II, ${ }^{10}$ more as product of contracting in the private placement and bank loan markets than in the bond market. The settled practice has been disrupted only once. During the 1970s, significant covenant protection disappeared from the debenture indentures of investment-grade issuers. Holders of those bonds later suffered a negative shock due to the high-leverage restructurings of the 1980s. The debt markets thereafter regained an equilibrium footing, even as contracting practice continued to evolve.

The European Union now repeats the American experience of more than a century ago. Centros, ${ }^{11}$ Überseering, ${ }^{12}$ and Inspire Art $^{13}$ usher in mobile incorporation for small firms seeking to escape national legal capital requirements. At the same time, critical questions ${ }^{14}$

conveyance statutes. For a complete description of the field, see B. Manning, Legal Capital, 2nd edn. (Mineola, Foundation Press 1982).

5 Hurst, op. cit. n. 1, at pp. 54-55.

6 See T. Banks, 'Indenture Securities and the Barkley Bill', 48 Yale L.J. (1939) p. 533 at p. 534. The indenture solved the enforcement problem by channeling performance rights through a trustee for the benefit of the holders of the bonds issued thereunder.

7 R. Garrett, 'A Borrower's View of the Model Corporate Debenture Indenture Provisions', 21 Bus. Law. (1966) p. 675 at pp. 678-680.

8 The modern private placement market developed in the wake of the federal securities laws and their requirement of issuer registration. See C. Rodgers, 'The Corporate Trust Indenture Project', 20 Bus. Law. (1965) p. 551 at p. 563.

9 A. Dewing, The Financial Policy of Corporations, Vol. 1, 5th edn. (New York, Ronald 1953) pp. 228-230 and (describing the development of the standard debt covenant after 1920 in response to evasions of negative pledge clauses).

10 See American Bar Foundation, Commentaries on the Model Debenture Indenture Provisions (Chicago, ABF 1971) [hereafter cited as ABF Commentaries]; B Graham, D. Dodd and S. Cottle, Security Analysis, 4th edn. (New York, McGraw-Hill 1962) pp. 332-335.

11 ECJ, Case C-212/97 Centros [1999] ECR I-1459.

12 ECJ, Case C-208/00 Überseering [2002] ECR I-9919.

13 ECJ, Case C-167/01 Inspire Art [2003] ECR I-10155.

14 See F. Kübler, 'The Rules of Capital under Pressure of the Securities Markets', in K. Hopt and E. Wymeersch, eds., Capital Markets and Company Law (Oxford, Oxford University Press 2003) p. 
arise respecting national legal capital rules governing publicly traded firms, along with the EC directive ${ }^{15}$ that embeds them in minimum form. Law reformers, looking to the US approach, envision a retreat to the insolvency standard. ${ }^{16}$

Business covenants figure in this debate. ${ }^{17}$ For legal capital's opponents they amount to a negotiated reproach to statutory mandate. No hard-wired code can duplicate their protective reach while simultaneously holding out comparable situation sensitivity. For legal capital's defenders, business covenants are beside the point. Nothing in a protective statutory regime prevents a financial creditor from negotiating for stricter protection. The statute's beneficiaries instead are trade creditors, for whom complex financial negotiations are not cost beneficial, and involuntary creditors, who get no chance to contract at all.

No efficiency template holds out a definitive resolution to these debates. The contractarians certainly make valid points: hard-wired equity capital mandates impose costs that deter entrepreneurship; lawmakers setting capital standards face an impossible task when they try to make trade-offs against an incomplete empirical background. At the same time, however, contractarianism never carries as an absolute in corporate debtor-creditor contexts. Limited liability flatly fails to pass efficiency inspection due to its allowance for externalization of risk on involuntary creditors. ${ }^{18}$ Some form of legal intervention accordingly is justified, and legitimate policy questions respecting creditor protection never disappear. It takes more effort to state an economic case for legal protection against opportunistic exploitation of unprotected voluntary creditors, but plausible cases have been made. ${ }^{19}$

This article looks at the US experience with contractual protection of financial creditors toward the end of gauging the robustness of the contractual alternative. The US experience is indeed pertinent for a Europe contemplating retreat from creditor protection in law. For more than a century, borrowers and lenders in the United States have contracted against a minimal legal background that imposes the burden of protection on the lender. A working, constantly

95 (emphasizing that strengthened equity markets reduce the need for creditor protective rules); J. Armour, 'Share Capital and Creditor Protection: Efficient Rules for a Modern Company Law', 63 Modern L. Rev. (2000) p. 355 (commending reform of UK company law). See also L. Enriques and J. Macey, 'Creditors versus Capital Formation: The Case against European Legal Capital Rules', 86 Cornell L. Rev. (2001) p. 1165. For the case in favor of retaining the rules on a default basis, see W. Schön, 'The Future of Legal Capital', 5 EBOR (2004) p. 429.

15 Second Council Directive 77/91/EEC of 13 December 1976 on coordination of safeguards which, for the protection of the interests of members and others, are required by Member States of companies within the meaning of the second paragraph of Article 58 of the Treaty, in respect of the formation of public limited liability companies and the maintenance and alteration of their capital, with a view to making such safeguards equivalent, OJ 1997 L 26/1.

16 See J. Rickford, ed., 'Reforming Capital: Report of the Interdisciplinary Group on Capital Maintenance', 15 European Business Law Review (2004) p. 919. See also Proposal for a Directive of the European Parliament and of the Council amending Council Directive 77/91/EEC, as regards the formation of public limited liability companies and the maintenance and alteration of their capital of 21 September 2004, COM (2004) 730 final.

17 Compare Armour, loc. cit. n. 14, at pp. 373-375, with Schön, loc. cit. n. 14, at p. 441.

18 See H. Hansman and R. Kraakman, 'Toward Unlimited Shareholder Liability for Corporate Torts', 100 Yale L. J. (1991) p. 1879.

19 See, e.g., L. Bebchuk and J. Fried, 'The Uneasy Case for the Priority of Secured Claims in Bankruptcy', 105 Yale L.J. (1996) p. 857 (contending that the US Bankruptcy Code's provision of full priority to secured claims can result in overall losses due to debtor incentives to create inefficient security interests favoring financial creditors at the expense of non-consenting tort and contract creditors). 
updated, set of contractual protections has emerged in response. Actual use of available contractual technology varies widely, however. This article reviews the usage pattern.

Three points emerge. First, contracting practice correlates directly with the level of risk. A borrower's incentive to externalize at its lenders' expense increases with the prospect of financial distress. The credit markets sort borrowers according to the degree of that risk, imposing substantial constraints on the borrowers with the most dangerous incentives. So salient is the prospect of opportunism on the part of a high-risk borrower that freely contracting actors can be counted on to cut that borrower little slack, at least where the size of the loan makes complex contracting cost beneficial.

Second, the contracting practice is sticky and lumpy, never quite managing to conform to the predictions of first generation agency theory. Levels of protection vary with institutional contexts, roughly paralleling well-known patterns of shareholder governance. Numbers count. Given a small number of institutional creditors, contracting can work the way it works in close corporations, providing something approaching full protection against agency costs. With debt, such substantial protection requires an exhaustive contract, and such an ex ante complete contract proves feasible only in a relational context conducive to ongoing renegotiation over time due to small numbers of actors operating under reputational constraints. The public bond markets do not hold out such a process context. They accordingly shut out the riskiest borrowers. The larger, less risky firms that do gain access to the bond markets borrow under contracts offering incomplete protection, with the level of protection roughly correlating to the borrower's risk level. Bondholders, like public shareholders, are left to rely on monitoring, exit, and diversification in dealing with agency costs. This has worked reasonably well in practice, subject to the exception of event risk. Event risk is the bond market's term for leveraged restructuring and other cases where a highly rated bond issuer changes its risk profile for governance reasons unrelated to the fundamentals of its business. Here the bond markets have thrashed about reactively looking for a stable solution for close to two decades, finally settling on across-the-board contractual protection only in recent years.

Third, no one knows what an optimal debt contract looks like. Any good bond lawyer knows how to draft a state of the art set of protections based on the past record of opportunistic debtor behavior. Borrowers and lenders negotiate against the background of that state of the art menu of protections, trading off the borrower's interest in business flexibility against the lender's interest in financial security. The practice is efficient in the sense that the contract fixes the trade and the market prices it. The more demanding task of explaining why each variation in the practice represents a superior trade-off of risk and return remains largely unperformed. This is not surprising. The theoretical economics of optimal capital structure also have yet to yield a robust efficiency prescription. ${ }^{20}$

The part by part analysis proceeds as follows. Part 2 describes the agency costs of debt, the economics describing borrower incentives to act in derogation of lender interests. Part 3 sets out the contractual response to agency costs, the 'full set' of business covenants. Part 4 describes the evolution of real world contracting, focusing on variations in levels of covenant protection in different markets for long-term credit. Part 5 describes the role business covenants play in distress situations, highlighting process problems that inhibit their efficient evolution.

20 See A. Reisz and K. John, Temporal Resolution of Uncertainty, the Investment Policy of Levered Firms, and Corporate Debt Yields, working paper (2002) p. 28, available at: $<$ http://ssrn.com/abstract=303339> (questioning whether an optimal capital structure can be derived at all in the context of presenting a model of optimal debt contracting under long-term uncertainty respecting the outcome of the firm's investments). 


\section{The economic framework: conflicts of interest and costly contracting}

Economic analysis of covenants still follows from foundational studies by Michael Jensen and William Meckling, ${ }^{21}$ Clifford Smith and Jerold Warner, ${ }^{22}$ and Stewart Myers. ${ }^{23}$ These describe four agency costs of debt - claim dilution, underinvestment, asset withdrawal, and asset substitution. ${ }^{24}$

\subsection{Claim dilution}

Claim dilution concerns the negative impact of subsequent borrowing on the value of an earlier loan. Assume that Firm A is worth 100 and has borrowed 50 from Lender 1 pursuant to an unsecured loan. The loan was priced on the assumption of no further borrowing by Firm A but contains no explicit restrictions. Firm A then borrows 35 from Lender 2 and invests the proceeds in a project that turns out to be worthless. Firm A emerges 85 percent levered. The interest rate on the second borrowing will reflect that possibility, compensating Lender 2, while the interest rate on the first borrowing does not compensate Lender 1. Lender 1's investment declines in value, with the benefits of the decrease accruing to Firm A and Lender 2. Lender 1 is even worse off if Lender 2 makes a loan secured by assets worth 35 . So long as the obligation to Lender 2 remains outstanding, the encumbered assets will not be available to satisfy Lender 1. Accordingly, Lender 1 must look for repayment to an asset base of 65 rather than the base of 100 envisaged at the time of the loan.

More generally, lenders, as fixed return claimants, can be injured by an increase in the amount of equal or prior claims in the borrower's capital structure. At the same time, borrowers have high-powered incentives to continue to borrow. Under the pecking order theory of finance, retained earnings are the cheapest source of finance, then debt, and, finally, new equity. ${ }^{25}$ Large new projects accordingly tend to mean an increase in debt claims. An increase in the level of debt can benefit the borrower's equity holders even in the absence of a new project. The new loan's proceeds can be siphoned out as a dividend, with the added claims increasing the borrower's leverage, turning it into a higher-risk, higher-return investment. Because the fixed return lender receives no extra compensation for that higher risk, the transaction transfers wealth from the lender to the borrower's equity holders.

If we change the facts of the hypothesis and price the first loan to reflect the possibility of claim dilution, there arises a basis for trade. Assume that Firm A is content to continue to finance all projects on a 50-50 debt/equity basis. A restriction on future borrowing, tied to a 50-50 debt/equity ratio, lowers the cost of the first loan without unduly inhibiting Firm A's freedom of action. The trade illustrates the costly contracting hypothesis of Smith and Warner. This assumes that the borrower bears the entire projected agency cost of a given issue of debt when the parties set the interest rate. It follows that the borrower's interest in minimizing its borrowing cost leads it to offer covenants that restrict its ability to take actions that benefit its shareholders while injuring its lenders' interests. The parameters of the restrictions offered follow from the borrower's cost-benefit calculation - Firm A trades off

${ }^{21}$ M. Jensen and W. Meckling, 'Theory of the Firm: Managerial Behavior, Agency Costs, and Capital Structure', 3 J. Fin. Econ. (1976) p. 305.

22 C. Smith and J. Warner, 'On Financial Contracting: An Analysis of Bond Covenants', 7 J. Fin. Econ. (1979) p. 117.

23 S. Myers, 'Determinants of Corporate Borrowing', 5 J. Fin. Econ. (1977) p. 147.

24 In the literature, the concept of 'asset substitution' encompasses the concept of 'asset withdrawal' used here.

25 See S. Myers, 'Capital Structure', 15 J. Econ. Perspectives (2001) p. 81 at pp. 91-93. 
the cost of future constraints on its freedom of action against the present benefit of a lower cost of borrowing.

\subsection{Asset withdrawal and underinvestment}

Assume now that Firm A, with assets worth 100 and debt claims of 85, owns asset $x$, valued at 10. Firm A sells $x$ to Firm B for 10 in cash, and then declares and distributes to its shareholders a dividend of 10. Because Firm A retains a net worth of 5 (and remains solvent on a going concern basis), the dividend is not a fraudulent conveyance. This asset withdrawal ${ }^{26}$ nonetheless materially injures the interests of Lenders 1 and 2 by reducing Firm A's net worth from 15 to 5. A covenant that blocks the sale of asset $x$ would enhance the positions of Lenders 1 and 2. But it would not protect them from all forms of asset withdrawal. Firm A might in the alternative liquidate an asset over time, directing the proceeds to its shareholders as received. Accordingly, Lenders 1 and 2 also need a covenant that prevents Firm A from transferring assets to its shareholders, by dividend or otherwise.

Claim dilution and asset withdrawal primarily concern wealth transfers from lenders to equity holders. Underinvestment has deeper implications for economic welfare. Assume that Firm A continues to decline in value, so that it now is worth 75 as against debt claims of 85 . It has the opportunity to invest in project $k$. Project $k$ is worth 10 . Firm A has no other available investment opportunities. Firm A will not make the investment, assuming an identity of interests among its managers and shareholders. From the point of view of Firm A's equity, project $k$ is worthless because its benefits redound entirely to Lenders 1 and 2 . Given limited liability, the equity might as well walk away. Alternatively, viewing the debtor-creditor relationship as an option in the equity to repurchase the firm from the debt at maturity, the shareholders of Firm A have an out of the money option to buy Firm A back from Lenders 1 and 2 for 85 . They have an incentive to invest in positive net present value (NPV) projects only to the extent the option is projected to expire in the money net of the investment. Firm A might pass up the investment even if project $k$ is worth 15 , depending on whether it deems the effort necessary to realize the project's value to be cost-beneficial for a return of $5 .^{27}$ The welfare cost stems from the decision to forego the investment. The lenders lose because the underinvestment heightens the risk of default, and, to the extent that no other firm is situated to pick up the opportunity, society as a whole also loses. A covenant blocking dividend payments addresses the problem indirectly, by leaving Firm A no alternative other than reinvestment for its free liquid assets. Drafting a contract term that directly forces Firm A to invest in project $k$ will turn out to be problematic, however.

\subsection{Asset substitution and risky investment}

To see the asset substitution problem, assume once again that Firm A is worth 75 as against debt claims of 85. Firm A owns asset $y$, and a potential buyer offers to buy $y$ for 20 in cash. If Firm A liquidates $y$ it can either pay the 20 to its lenders or invest in $z$. Asset $z$ has an expected value of 20, based on the following projection: (a) a 10 percent chance that $z$ turns out to be worth 200, and (b) a 90 percent chance that $z$ turns out to be worthless. If the expected value of 20 is discounted to reflect the high risk of a zero return, the NPV of $z$ turns out to be less than 20. It nonetheless is rational for Firm A to make the investment. If the long shot comes in, Firm A is worth 255; if the investment is worthless, Lenders 1 and 2 bear the cost of the loss. Alternatively, once again viewing the debtor-creditor relationship as an

${ }^{26}$ See D. Fischel, 'The Economics of Lender Liability', 99 Yale L.J. (1989) p. 131 at pp. 134-135.

27 Myers, loc. cit. n. 23, at pp. 164-165. 
option, the shareholders of Firm A have an out of the money option to buy A back from Lenders 1 and 2 for 85 . Viewed as a long holding, investment $z$ is irrational due to its negative net present value. But if the equity is viewed from an option holder's point of view, $z$ makes the option more valuable by increasing the volatility of the underlying asset's returns. The shareholders thus have an incentive to make an investment that decreases economic welfare, with the cost falling on the firm's lenders.

This asset substitution problem combines two actions by Firm A - the sale of asset $y$ and the investment in risky asset $z$. The asset withdrawal problem already has demonstrated the value of a contract term blocking large asset sales. The underinvestment problem suggested a need for a contractual means to force Firm A to make a valuable investment for the benefit of its lenders. Now we see the need for a term that prevents Firm A from making a suboptimally risky investment.

\subsection{Distress, prosperity, and the debt-equity conflict of interest}

Debt-equity conflicts of interest intensify as leverage increases and, with it, the prospect of default on the debt. New borrowing need not be implicated - leverage also increases if the firm's value falls relative to its existing debt. Either way, rising leverage increases the probability that the lenders take a disproportionate share of the returns of new investment, increasing the possibility of underinvestment, ${ }^{28}$ simultaneously magnifying the incentive to make high-risk investments at the lenders' expense. ${ }^{29}$ High leverage also increases the prospect of payment default, further decreasing the debt's value. Extreme financial distress means bankruptcy, and bankruptcy entails deadweight $\operatorname{costs}^{30}$ that independently decrease the value of the firm. The agency costs of debt, then, are the costs of financial distress.

Now consider the converse scenario: Firm A borrows from Lenders 1 and 2 and prospers. Assume that the debt contracts contain covenants that (a) restrict any future borrowing by Firm A; (b) restrict dividends and share repurchases to a small percentage of annual net earnings; and (c) block substantial asset sales. At the time of Lender 2's loan, Firm A has assets of 135 and debt of 85, leaving an 'equity cushion' of 50. The purpose of the covenants is to lock in the equity cushion as a source of value available to pay the loans. Five years later, Firm A's assets are 300 and its debt is still 85. As the equity cushion becomes larger, the loans become less risky, and, all other things being equal, increase in value. More generally, with a full set of covenants and a successful borrower, the lender's position becomes more secure over time. This reverses the wealth transfer - now the lenders gain at the shareholders' expense. Firm A can draft its debt contracts to protect its equity from this result. The covenants can be drafted so as to condition constraints on stated financial conditions, so that the restraints relax as Firm A becomes more valuable. Alternatively, Firm A can reserve a power to prepay ('call') the principal amount of the loan.

\section{The full set of covenants}

28 See Z. Bodie and R. Taggart, 'Future Investment and the Value of the Call Provision on a Bond', 33 J. Fin. (1978) p. 1187.

29 See Jensen and Meckling, loc. cit. n. 21, at p. 342 (agency costs of debt include opportunity wealth loss caused by the effect of debt on investment decisions and bankruptcy costs).

30 See, e.g., L. Weiss, 'Bankruptcy Resolution: Direct Costs and Violation of Priority Claims', $27 \mathrm{~J}$. Fin. Econ. (1990) p. 285 (showing direct costs as 3 to 7 percent of firm value); J. Warner, 'Bankruptcy Costs: Some Evidence', 32 J. Fin. (1977) p. 337 at p. 343 (studying eleven railroad bankruptcies between 1930 and 1955 and concluding that a bankruptcy costs an average of 2.5 percent of firm value during the three years preceding the bankruptcy). 


\subsection{Affirmative and negative}

In US practice, ${ }^{31}$ business covenants make a formal distinction between affirmative promises and negative promises. Affirmative covenants go only to ministerial matters. For example, the borrower in a private placement or bank term loan will affirmatively promise to make periodic informational reports. It also will make positive promises to comply with law, maintain its franchises, insure and maintain its properties, and pay all properly assessed taxes. While all of these promises imply costs, ${ }^{32}$ none of them materially constrains management's discretion to operate the business. In contrast, covenants that protect the lender from claim dilution, asset withdrawal, underinvestment, and asset substitution can materially constrain the business judgments of the borrower's managers. These terms invariably are phrased in the negative.

Limited liability is the reason. Under US corporate law, when a creditor, acting in that capacity, exercises control power over the firm, it loses its limited liability status. If a managing creditor's business decisions work out badly, it can be held personally liable to other creditors or even to the stockholders. ${ }^{33}$ Lenders 1 and 2, accordingly, will not reserve a contractual power to direct Firm A to invest in project $k$. If they are careful, they will not even extract affirmative promises from Firm A to invest the proceeds of their loans in the projects outlined by Firm A during negotiations. Firm A, instead of making a promise in the debt contract respecting the project, will formally represent its present intent to make the investment. Firm A, however, will not be situated so as meaningfully to represent its present intentions concerning future business decisions. At the same time, liability risk constrains the lenders from seeking direct control over Firm A's future business decisions. They accordingly seek to influence Firm A's future conduct indirectly, by specifying default events ex ante in negative covenants. Exercise of such indirect control presupposes contractable subject matter. Promises not to borrow, pay dividends, or sell assets all fall into this category. Advance specification respecting investment policy proves more difficult.

The longer the list of prohibited outcomes, the stronger the control. At some point the magnitude of control becomes so great as to give the lender effective control of the firm. This invites a substance over form argument by an objecting equity holder seeking to make out a

31 For legal commentaries on business covenants, see $A B F$ Commentaries, op. cit. n. 10; R. Nassberg, The Lender's Handbook (Philadelphia, ALI 1986); R. Lloyd, 'Financial Covenants in Commercial Loan Documentation: Uses and Limitations', 58 Tenn. L. Rev. (1991) p. 335; M. McDaniel, 'Are Negative Pledge Clauses in Public Debt Issues Obsolete?' 39 Bus. Law. (1983) p. 867; D. Simpson, 'The Drafting of Loan Agreements: A Borrower's Viewpoint', 28 Bus. Law. (1973) p. 1161.

32 The more costly promises on the list will be negotiable accordingly. See ABF Commentaries, op. cit. n. 10, at pp. 312-313.

33 The classic case, Martin v. Peyton, 246 N.Y. 213, 158 N.E. 77 (1927), concerns a loan to a partnership. The liability of bank lenders to small businesses is the subject of leading cases in recent decades. See, e.g., K.M.C. Co. v. Irving Trust Co., 757 F. 2d 752 (6th Cir. 1985); State Nat'l Bank of El Paso v. Farah Mfg. Co., 678 Sw. 2d 661 (Tex. Ct. App. 1984). See generally M. Douglas-Hamilton, 'Creditor Liabilities Resulting from Improper Interference with the Management of a Financially Troubled Debtor', 31 Bus. Law. (1975) p. 343. There is a way to deflect this risk for a creditor with control power. If the creditor is a human being it forms a wholly-owned shell corporation or limited liability company to hold the debt; if the creditor is a corporation, it forms a shell wholly-owned subsidiary. Both steps are costly, and there remains a residual risk of veil piercing. A creditor simultaneously holding a controlling block of shares puts the shares into a voting trust, divesting itself of control by delegating discretion respecting the vote to an independent trustee. 
case of lender liability. Courts, however, respect the formal distinction, and bond lawyers proceed with confidence in the negative framework.

\subsection{Negative covenants}

The following sections outline the 'full set' of negative covenants.

\subsubsection{Restrictions on debt}

Debt covenants protect against claim dilution by regulating the incurrence of new debt, allowing it when justified by the firm's financial condition. They tend to set out ratios of net tangible assets to total debt and ratios of earnings available to pay debt to debt service costs, ${ }^{34}$ permitting new debt to be incurred to the extent that the tests are met. The targeted transactions are borrowings of money. Other transactions booked on the balance sheet's liability side, trade credit most importantly, are not customarily covered. On the other hand, debt covenants tend to restrict transactions that lenders view as the functional equivalent of borrowing, such as financial leases and the guaranties of the obligations of others. Debt covenants also can make structural distinctions between short-term borrowing and long-term debt and between subordinated and unsubordinated debt. For example, the borrowing window can be made larger for new borrowing subordinated to the loan covered by the covenant.

Debt covenants protect the lender from an increase in the number of claims on the equity cushion and the risk of insolvency. They also indirectly discourage risky investments - risky debt and risky investments tend to be concomitants. The constraints are unlikely to be absolute, however. Assuming a healthy borrower with prospects for growth, the debt covenant protects the borrower's freedom of action by restricting and regulating new debt incurrence rather than prohibiting it absolutely. The window of freedom also can hold out an incidental benefit for existing lenders. Additional debt can provide the borrower with additional capital for good projects the returns on which make existing lenders more secure. Put differently, flexibility respecting additional debt ameliorates the underinvestment problem.

The regime of flexibility may not, however, extend so far as to permit borrowing by subsidiary companies. To see why not, hypothesize a firm made up of two operating companies, Subsidiary 1 and Subsidiary 2, each 100 percent owned by a holding company, $\mathrm{HC}$. $\mathrm{HC}$ is the borrower on a loan with Lender $\mathrm{HC}$ under a debt contract that restricts borrowing by $\mathrm{HC}$ but not by Subsidiaries 1 and 2. HC causes Subsidiary 1 to borrow heavily from Lender S. Because Subsidiary 1 is an entity separate from $\mathrm{HC}, \mathrm{HC}$ is not a party to the debt contract with Lender S. Subsidiary 1 becomes insolvent and goes into bankruptcy reorganization. Although Subsidiary 2 remains profitable, HC goes into default on its debt and is itself forced into reorganization. When the smoke clears, Lender HC will be

34 Asset-based tests are variously stated. For example, the tangible net worth may substitute for net tangible assets, and funded debt may substitute for indebtedness. Borrowings for the purpose of paying down debt of the same or higher priority often are permitted explicitly. See R. Nash, J. Netter, and A. Poulsen, 'Determinants of Contractual Relations between Shareholders and Bondholders: Investment Opportunities and Restrictive Covenants', 9 J. Corp. Fin. (2003) p. 201 at p. 215.

These accounting-based tests will be based on results reported under US Generally Accepted Accounting Principles (GAAP), but the contract often modifies GAAP results. For example, assetbased tests may require the borrower to deduct intangible assets booked on its balance sheet's left side, producing ratios of 'hard' assets to total liabilities. 
subordinated to Lender S so far as concerns the proceeds of Subsidiary 1's bankruptcy proceeding. Lender $\mathrm{HC}$ has a claim only on the assets of $\mathrm{HC}$, and $\mathrm{HC}$ can establish a claim in Subsidiary 1's bankruptcy only in its capacity as Subsidiary 1's equity claimant. As an equity claimant, it is subordinated to Lender S. Even if Lender HC emerges from HC's bankruptcy holding HC's entire value, to the extent that Lender S's claim exceeds the value of Subsidiary 1 's assets and wipes out HC's equity, Lender HC receives no proceeds from Subsidiary 1. A properly drafted debt covenant solves the problem: HC must promise not to permit its subsidiaries to borrow except from HC. HC's freedom of action is not thereby drastically constrained. If it wishes to procure debt financing for Subsidiary 1, it first borrows in its own name and then reloans the proceeds to Subsidiary 1. This way the borrowing is tested under HC's own debt covenant, and, in the event Subsidiary 1 becomes insolvent, the sole senior claimant is HC, preserving HC's senior position respecting Subsidiary 1's assets.

Extending the point, Lender $\mathrm{HC}$ also benefits from a covenant that prevents sales of additional equity to third parties by Subsidiaries 1 and 2 . Direct equity financing by the subsidiaries makes HC, and hence its lenders, pari passu claimants to the subsidiaries' assets with the new shareholders. From Lender HC's point of view, new equity financing for the $\mathrm{HC}$ group should be accomplished directly through an equity offering by HC. As to these new equity holders, Lender $\mathrm{HC}$ is completely senior. If $\mathrm{HC}$ wants to invest the proceeds of such an equity financing in Subsidiary 1, it can siphon the capital downward either by taking additional subsidiary stock or making an intercompany loan.

\subsubsection{Restrictions on prior claims}

Covenants restricting mortgages and liens are the second principal protection against claim dilution. Unsecured creditors can look only to the borrower's unencumbered property; to the extent the property is subject to mortgages, security interests, or other liens, it is not available to pay their claims in liquidation. Secured creditors, moreover, are accorded priority in bankruptcy reorganization to the extent of the value of the property covered by their liens. Contracts governing unsecured debt accordingly tend to restrict the creation of new liens. There are two modes of drafting the restriction. The first imposes a direct and sweeping prohibition, subject to negotiated exceptions. Exceptions are most likely to be granted for purchase money mortgages and security interests. Such a rigid drafting technique is more likely to be employed in a private placement or bank term loan than in a public bond offering. The second mode of approach is the 'negative pledge' covenant. This comparatively simple provision states that no lien will be created unless the lien also equally and ratably secures the debt benefited by the provision. This version tends to show up in indentures covering public bond issues. ${ }^{35}$

Separate sale and leaseback prohibitions also will be found in many debt contracts. Sale and leaseback transactions take assets presently owned by the borrower and available to pay the lender and transfer title to them to a third party, with the seller-borrower emerging holding a lease on the sold premises with the buyer as lessor. Lenders view such a transaction as an extreme form of secured borrowing on the asset. The borrower sells a factory and pockets the sale price, even as the simultaneous lease back lets it leave its existing facility in

35 See C. Bjerre, 'Secured Transactions Inside Out: Negative Pledge Covenants, Property, and Perfection', 84 Cornell L. Rev. (1999) p. 305. A negative pledge does not necessarily disable a subsequent secured loan. Suppose Firm A has assets worth 100. Debt claims of Lender 1, covered by a negative pledge clause, total 15. Firm A wishes to borrow an additional 15 from Lender 2 on a secured basis. All of its 100 of assets are unencumbered. Firm A can borrow from Lender 2 on a secured basis so long as Lender 1 also is secured by the lien. The transaction will satisfy Lender 2 so long as the lien covers property worth 30, thereby fully securing Lenders 1 and 2 . 
place. The purchaser of the property holds a superior title to the property, which will not be available for inclusion in the estate in a borrower bankruptcy. To see the depth of a lender's aversion to such a transaction, compare a mortgage loan secured by the same factory. With a mortgage, the borrower builds up equity in the property as it pays the loan over time, further benefiting to the extent the property appreciates in value. With the sale/leaseback, the borrower starts out with a 100 percent equity interest in the property, which is transferred away. It thereafter makes lease payments over time, ending up with nothing at the lease's expiration. Furthermore, the funds generated by the sale readily can be redirected to investment in riskier assets, or, alternatively, withdrawn from the firm's asset base and distributed to its shareholders. Sale/leasebacks, in short, are just the sort of transactions entered into by cash-strapped firms - this single transaction can implicate claim dilution, asset withdrawal, asset substitution, and risky investment.

\subsubsection{Restrictions on dividends and other payments to shareholders}

These covenants restrict transfers of corporate assets to shareholders, whether by way of a dividend or a redemption or repurchase of outstanding stock. The restriction typically operates by reference to the borrower's profitability: the covenant sets a base date, usually at or near the time of the loan, and permits dividends and redemptions only to the extent of cumulative earnings after that date, and then only up to a given percentage or amount. A fixed sum (the 'dip') may be added to the cumulative sum of earnings, increasing the total allowed sum for distributions. In addition, credit might be given for the proceeds of the sales of new equity. Bank loans can include more finally tailored variations on the theme, specifying maximum dividend amounts for given periods, limiting the frequency of dividends, and conditioning payments on stated tests such as credit ratings and financial ratios. ${ }^{36}$ Finally, dividend covenants can be tied to other covenants in the full set - the dividend can be conditioned on the existence of room to borrow under the debt covenant and compliance with all covenants ex post the dividend.

The covenant serves multiple purposes. First, it prevents asset withdrawals that injure the lender's interest by locking in the firm assets at least equal in amount to those present at the time of the loan. Second, the covenant enhances the lender's position during the term of the loan. For example, if the permitted distribution amount grows as a function of 50 percent of annual earnings, then half of the incremental growth of the asset base remains contained in the borrower entity, making the loan more secure and enhancing its value. Finally, the covenant discourages underinvestment. As we have seen, as the borrower declines in value, at some point new investment redounds only to its lenders' benefit. Should such a declining business be generating free cash flow, whether from operations or as the result of disinvestment, a dividend amounts to the funds' best use from the shareholders' point of view. The covenant blocks the escape route, forcing the borrower to invest the funds for the lenders' benefit.

Such projects could hold out negative NPVs. From an equity holder's point of view, a project is suboptimal if it returns less than the cost of equity capital; under basic financial economics, funds should be paid out to the shareholders absent investments returning more than the cost of equity capital. Things look very different from a lender's point of view, however. As between a payout to shareholders and reinvestment, any investment yielding a positive cash return, no matter how low, is superior. Even a zero return investment enhances the asset base available to pay the debt. Despite this, the dividend covenant holds out only a

${ }^{36}$ M. Bradley and M. Roberts, The Structure and Pricing of Corporate Debt Covenants, working paper (2004) p. 12, available at: <http://ssrn.com/abstract=466240>. 
minimal threat to economic welfare. So long as the loan remains outstanding, the borrower without positive investment projects can always direct its free cash flows to repayment of the loan's principal amount. In any event, as with the debt covenant, the typical dividend covenant stops well short of absolute prohibition.

Of course, only small subset of mature US firms pays regular dividends. ${ }^{37}$ Lenders need the covenant nonetheless. Circumstances easily can change over a loan's ten or fifteen-year term so as to favor a shareholder distribution. Moreover, a distribution need not entail the implicit commitment of a regular dividend. For example, if the firm generates free cash flow in the face of a diminishing set of new investments, a program of open market stock repurchases can pump out the money so as to suit the interests of both outside shareholders and managers benefited by equity incentive plans.

\subsubsection{Restrictions on mergers and sales of assets}

A merger with another operating company can injure a lender even though the surviving corporation is a larger firm. Claim dilution can follow if the merger partner is highly levered. Alternatively, the merger partner could have a riskier business so that the merger effects a detrimental investment policy shift. A sale of all or substantially all of the borrower's assets can raise the same problems in aggravated form - such a transaction literally separates the assets supporting the loan from the corporate entity that entered into the debt contract; absent covenant protection, the lender can be left looking to a shell entity for satisfaction. In contrast, a merger into a shell acquisition subsidiary organized by a conservatively managed acquiring firm may be a matter of indifference or benefit to the lender.

Covenants dealing with prospective mergers and acquisitions range from very permissive to very strict. With public bond issues, mergers and sales of all or substantially all assets may be permitted subject to two conditions: the purchasing firm (a) must be organized within the United States, eliminating the possibility of an offshore bankruptcy proceeding, and (b) must formally assume the debt. Private placements and bank term loans likely will impose additional constraints - a transaction will be permitted only so long as the survivor or purchaser has room to borrow under the debt covenant and can demonstrate compliance with every other covenant ex post the closing of the merger. There are other available modes of regulating these transactions. For example, they may be permitted subject to a right of redemption in the lender.

Piecemeal sales of assets hold out problems of asset withdrawal and risky investment policy. Any sale of producing assets raises questions respecting the adequacy of the sale price and the reinvestment of the proceeds. In an extreme case, an asset sale can imply complete redirection of the business. For example, a firm could sell off pieces of itself over a period of time and reinvest the proceeds in a riskier line of business. Covenants regulating these transactions tend to put a book value or fair value cap on the aggregate annual permissible saleable assets, along with a fair value standard to govern the terms of permitted sales.

Borrowers will likely see asset sale constraints as significant and undesirable impairments of their freedom of action. Today's managers actively trade subsidiaries and divisions in a market for going concern assets. They also enjoy increased access to liquidity. Consider a standard asset securitization - the firm sells its accounts receivable for cash to an off balance sheet special purpose entity, the equity of which is held by third parties. Such a transaction falls within the scope of a traditional covenant barring piecemeal asset sales. Whether such a transaction negatively implicates a legitimate interest of a lender depends on the case. On the one hand, liquidation of receivables could advance the borrower's investment program,

37 W. Bratton, 'The New Dividend Puzzle', 93 Geo. L. J. (2005) p. 845 at pp. 849-852. 
benefiting the lender. In the alternative, the proceeds could be devoted to riskier investments or open market stock repurchases.

\subsubsection{Restrictions on investments}

A debt contract easily can ameliorate the problems of asset substitution and risky investment by barring sales of assets in excess of, say, 10 percent of net worth per year. It is more difficult for a debt contract to take the next step of directing the use of proceeds of particular asset sale to a particular project viewed with favor by the lender. The limited liability constraint prevents the dictation of positive instructions. Sets of negative instructions drafted in advance are ill-suited as substitutes for sound investment choices. At best, the drafter can craft an instruction keyed to positive net present value projects, or an instruction keyed to a specified hurdle rate or a hurdle rate calculation. But the factors in question present verification problems and therefore would be expensive to monitor. ${ }^{38}$ The interests of both parties thus signal a strategy of indirect constraint of investment policy.

Debt contracts accordingly seek to constrain risky investment by blocking off definable and speculative investment alternatives. The covenants target investments in liquid and intangible assets, forcing the borrower to take its free cash flow to safe, short-term investments such as treasury securities or certificates of deposit, and prohibiting outlets like portfolios of common stocks and futures contracts. In effect, the borrower is forced to devote its capital to its going concern business. A companion covenant will foreclose resort to alternative lines of business by requiring the borrower to stay in its present line of business.

These two covenants, taken together with the covenant barring asset sales, effectively prevent asset substitution and risky investment. They would, for example, prevent a borrower dissatisfied with the return on its present line of business from changing the profile of its going concern by acquiring a high-tech, high-risk subsidiary firm. They also would prevent a borrower in distress from liquidating going concern assets and putting the proceeds into highrisk, high-return financial assets. Taken together with the dividend covenant, the investment covenants also address the underinvestment problem. The investment covenant restricts the set of available investments for the borrower's free cash flow, while the dividend covenant blocks the payment of the free cash flow to the shareholders. Given spare cash and no attractive reinvestment opportunities in the going concern, the borrower's best returns on free capital may come from prepayment of the loan.

Managers are especially likely to resist restriction of discretion to make investments. Accordingly, these covenants are likely to appear only in private placements and bank loans in which the lender has substantial bargaining power.

\subsubsection{Early warning covenants}

Recall that the agency costs of debt are the costs of financial distress. When distress looms, lenders can benefit from an occasion for contract renegotiation. Toward the end of opening such a zone of freedom of action for the lender, some debt contracts contain financial maintenance tests. These tend to set a minimum level of net worth (assets minus liabilities), either as a dollar amount or a ratio. A net worth test establishes the smallest equity cushion that the lender must tolerate. Failure to meet the test functions as an early warning of distress. Such a borrower must either raise equity capital, go into default, or persuade the lender to waive the default. Toward the same end, a covenant may set a minimum ratio of cash flow to current payments of interest and principal on debt. Some contracts also include tests of

38 See Myers, loc. cit. n. 23, at pp. 156-158; Smith and Warner, loc. cit. n. 22, at p. 153. 
working capital (current assets minus current liabilities), either as a dollar amount or as a ratio. Here, failure to meet the test gives the lender an early warning of a liquidity crisis.

The lender may profit little if it takes the occasion of a violation of one of these covenants to exercise its rights in full by declaring an event of default and accelerating the loan. Acceleration as practical matter forces the borrower to make a defensive bankruptcy filing. Bankruptcy entails not only deadweight costs but uncertainties respecting proceeds available for classes of unsecured lenders. The value of early warning covenants more likely lies in negotiation. The lender may be able to trade a waiver of the default for enhanced contract rights - stricter covenants, a higher interest rate, or an unscheduled prepayment. ${ }^{39}$ Without the covenant, the lender does not necessarily have a basis on which to force a distressed borrower to enter into a conversation, much less to improve its standing, even as better protected interest holders may take the occasion to impose demands, perhaps extracting preferential payments.

\subsubsection{The prepayment alternative}

Shorter-term loans by banks commonly employ an alternative means to the end of protecting against claim dilution and asset substitution. Under these, a subsequent borrowing, equity offering, or asset sale triggers a duty to pay down all or part of the loan. ${ }^{40}$ The provisions, termed 'sweeps', tie the magnitude of the triggering event to a percentage of the loan to be paid down - for example, an asset sale exceeding a stated amount or percentage of net assets triggers a duty to pay down 50 percent of the loan. Note that in the case of a sweep covering subsequent borrowing or equity issuance, the provision signals that both the bank and the borrower see the loan as an interim feature of the borrower's capital structure - the deal contemplates that the subsequent financing takes out the bank. In contrast, an asset sale sweep plays the more conventional agency cost control function. Note finally that a prepayment also can be achieved under a conventional covenant - the lender waives the covenant in exchange for a negotiated prepayment out of the proceeds of the asset sale. The difference is that under a conventional covenant the result obtains only as the outcome of a renegotiation, whereas under a sweep it follows as a matter of right.

\subsection{Event risk}

Leveraged restructuring holds out an instructive test of the efficacy of the full set of business covenants. Under the textbook 'management buyout' or 'going private' transaction, a financial promoter joins with the top managers of a publicly traded company (the 'target' firm) to borrow funds to purchase the target from its shareholders at a premium over the market price of the stock. Critically, the target's own assets provide the borrowing base. The means to the end is a merger of the target into a shell corporation organized by the promoters. The merger pays the target shareholders cash, with the loans providing the cash closing simultaneously with the merger, so that the surviving entity that serves as the obligor on the loans possesses the target's assets. The surviving entity emerges privately held and highly levered. The 1980s 'bust-up' hostile tender offer proceeded on the same economics. The hostile offeror, a shell entity without producing assets of its own, made a cash tender offer for

39 For empirical studies of negotiations in the wake of early earning default, see M. Beneish and E. Press, 'Costs of Technical Violation of Accounting-Based Debt Covenants', 68 Accounting Rev. (1993) p. 233; K. Chen and K. Wei, 'Creditors' Decisions to Waive Violations of AccountingBased Debt Covenants', 68 Accounting Rev. (1993) p. 218.

40 See Bradley and Roberts, op. cit. n. 36, at p. 11. 
the shares of the target. It financed the tender offer with debt, simultaneously closing the tender offer, the loans, and the merger of the target into the acquisition shell.

Given a full set of covenants, neither transaction can close without the occurrence of an event of default. The massive borrowing needed to take out the common stockholders violates the debt covenant. A merger covenant conditioning the existence of room to borrow under the debt covenant ex post the closing of the merger independently blocks the deal. Closing the deal accordingly means prepaying all covenant-protected loans. That by itself does not necessarily foreclose the transaction - new borrowing can fund the prepayment of old borrowing in addition to funding the merger consideration paid to the exiting public shareholders. At the margin, sums diverted to old debt reduce the premium paid to the shareholders.

Large US corporations experienced a wave of leveraged restructurings between 1984 and 1989. Hostile tender offers triggered the wave, with defensive management buyout transactions occurring in response and increasing the number of transactions. Both caused considerable dislocation in the bond market. Unfortunately for the bondholders, by 1984 trust indentures governing the long-term unsecured debt of investment-grade issuers ${ }^{41}$ no longer contained full sets of covenants. Since the mid-1970s, new public, unsecured debt of large industrials had tended to contain only negative pledge and sale-leaseback covenants. Debt and dividend covenants had disappeared, surviving to restrain only smaller, non-investmentgrade issuers. $^{42}$

Debt contracting practice had changed. For most of the twentieth century, the norm had been substantial protection, if not the full set of covenants then a partial set containing debt and dividend restrictions. The degree of constraint depended on the borrower's credit standing. Better credits with access to public bond markets faced fewer restraints than smaller issuers making private placements. The best credits issued debt with no restraints other than a debt covenant. ${ }^{43}$ That changed in the mid-1970s. Managers of top-rated issuers began to resist debt covenants as unnecessary constraints. ${ }^{44}$ The bondholders conceded the point, relying on a perceived common interest. Management wanted steady growth and security goals best realized with conservative leverage and retained earnings financing. According to

${ }^{41}$ Issuers pay two firms, Moody's and Standard \& Poor's to rate their debt for creditworthiness. The firms assess the likelihood of default and do not cover the risk of changes in interest rates. Under Moody's rating system, 'high grade' is AAA and AA; 'medium grade' is A and BAA; 'junk' is $\mathrm{BA}$ and B; CAA and CA are lower still; $\mathrm{C}$ is in default. A 1, 2 or 3, added to a Moody's rating functions like a plus or a minus, with a 1 being a plus. Standard \& Poor's rates between AAA and D (default). Junk is below BBB.

42 Smith and Warner's survey of 87 bonds issued between 1974 and 1975 showed that 90.8 percent contained debt covenants, 23 percent contained dividend covenants, 39.1 percent restricted mergers, and 35.6 percent restricted asset sales. Smith and Warner, loc. cit. n. 22, at p. 123. McDaniel surveyed the debt contracts of Fortune's 100 largest industrials in 1984. He found that negative pledge and sale-leaseback covenants were ubiquitous. Of the 92 companies reported as having one or more senior issues, one or more subordinated issues, or both, only 28 percent of the issues contained debt covenants. Of the newer issues, only 16 percent contained a debt covenant. Dividend restrictions appeared in 35 percent of the issues, but in only 20 percent of the newer issues. See M. McDaniel, 'Bondholders and Corporate Governance', 41 Bus. Law. (1986) p. 413 at pp. 425-426. Malitz surveyed all long-term senior non-convertible debentures issued between 1960 and 1980 and described in Moody's Bond Survey or Moody's Industrial Manual. Of these, 49 percent contained no debt covenant. Malitz found a negative correlation between the presence of debt covenants and the size of the issuer. See I. Malitz, 'On Financial Contracting: The Determinants of Bond Covenants', Fin. Mgt. (Summer 1986) p. 18 at pp. 21-24.

43 Simpson, loc. cit. n. 31, at pp. 1161-1162.

44 See McDaniel, loc. cit. n. 42, at pp. 236-238. 
the conventional wisdom at the time, any opportunistic conduct detrimental to the bondholder interest would lead lenders in future financings to impose unfavorable terms, the costs of which would outweigh the benefits of any present wealth transfers. ${ }^{45}$

Other factors also contributed to the shift. Actors in the bond market perceived a shift in supply and demand and remarked on a shift from 'sold' to 'bought' deals. As more money looked for investment-grade issues, the issuers seized the resulting bargaining advantage and took the occasion to change the terms of the deal. Changes in holding patterns certainly also contributed. Individuals disappeared from the market to be replaced by institutional holders with diversified portfolios. Interest rate shocks and deregulation in the 1970s and 1980s turned the institutions into more active portfolio managers. Bond trading markets grew and thickened. The earlier conservative pattern, under which the lender expected to hold the bonds to maturity and both parties linked the loan's maturity to the lifetime of a capital investment made by the borrower, no longer invariably shaped the terms of transactions. ${ }^{46}$

The unprotected bonds were hard hit by high-leverage restructurings. As the 1980s unfolded, what had looked like an independent, diversifiable source of risk became a systematic risk for investment-grade portfolios. Waves of restructurings triggered massive transfers of wealth from bondholders to target shareholders. Upon announcement, issuer stock jumped up, with bond prices suddenly dropping and rating downgrades soon following. ${ }^{47}$ (Overall welfare losses were not implied however - gains on the stock vastly outstripped losses on the bonds. ${ }^{48}$ ) Rating agencies quickly began to evaluate restructuring risk, termed 'event risk', with downgrades becoming common for firms deemed vulnerable. The bondholders discovered something that Jensen and Meckling had noted in 1976: sainthood does not have infinite benefits, and agency costs do not reduce to zero. ${ }^{49}$ Power over investment and financing shifted to capital markets profiting from shareholder value enhancement. Corporate reputation - the unprotected bondholders' backstop - proved an inadequate substitute for explicit contractual promises.

Implied-in-law fairness duties also proved an inadequate substitute for explicit promises. At the start of the 1980s, it had looked otherwise. The proposition that all contracts should be subject to an implied covenant of good faith and fair dealing had only recently appeared in US contract law. The new Restatement (Second) of Contracts held out good faith as a general, backstop duty for the benefit of parties without specific protective contract provisions who suffered injury due to opportunistic actions of contract counterparties. The doctrine presumed contracts to be incomplete and invited courts to interpolate terms to protect victims. No doctrinal barrier blocked the concept's application to the bondholders' restructuring losses - no one had anticipated the combination of massive borrowing and asset

45 R. Taggart, 'The Growth of the "Junk" Bond Market and its Role in Financing Takeovers', in A. Auerbach, ed., Mergers and Acquisitions (Chicago, University of Chicago Press 1988) p. 5 at p. 19.

46 J. Van Horne, Financial Management and Policy, 6th edn. (Englewood Cliffs, Prentice Hall 1983) pp. 507-509, 513-515.

47 The 1988 RJR Nabisco leveraged buyout is the most famous example. When the transaction was announced, the price of RJR Nabisco stock jumped $\$ 21.38$ to $\$ 77.25$. The bonds plummeted; some falling as much as 20 points, or $\$ 200$ per $\$ 1,000$ face value. Fear that the RJR deal heralded a wave of similar transactions caused a near halt to trading in high-grade corporate bonds. See W. Bratton, 'Corporate Debt Relationships: Legal Theory in a Time of Restructuring', 1 Duke L. J. (1989) p. 92 at p. 94. Aggregate data show an average announcement period loss of 6 to 7 percent of bond value in the wake of a leveraged buyout. See A. Warga and I. Welch, 'Bondholder Losses in Leveraged Buyouts', 6 Rev. Fin. Studies (1993) p. 959.

48 Bratton, loc. cit. n. 47, at pp. 138-139.

49 Jensen and Meckling, loc. cit. n. 21, at p. 351. 
withdrawal by investment-grade firms. But courts in the 1980s closed the door to good faith claims under long-term debt contracts, with the leading case, Metropolitan Life Insurance Co. v. RJR Nabisco, Inc., ${ }^{50}$ concerning bonds without covenants and high-leverage restructuring. The lesson was simple: bond contracts were presumptively complete. In the courts' view, lending relationships proceed at arm's length among highly sophisticated parties ${ }^{51}$ fully capable of negotiating protection. A court implying additional terms ex post would frustrate their intent and add unneeded uncertainty. Therefore, absent an explicit contract term, there should be no legal constraints on borrower opportunism; ${ }^{52}$ no good faith (or fiduciary) duties run from the borrower to the bondholders unless the opportunistic conduct cited happened to violate an explicit clause of the contract. Of course, to require an explicit contract term in a good faith case is the same thing as saying there is 'no good faith duty'. ${ }^{53}$

The job of protecting bondholders against event risk eventually and inevitably fell to bond lawyers at the drafting table. They devised terms called 'super poison puts' or 'event risk provisions'. The protection came from a right to put the bonds back to the issuer at par or, in a minority of instances, from a right to an upward interest rate adjustment tied to a change in credit rating. The right, whether a put or a rate adjustment, was triggered by defined events, generally mergers and acquisitions (including management buyouts), significant changes in the composition of the board of directors, and downward rate adjustments to below investment grade. A 'dual trigger' provision appeared most frequently. Under this provision, the combination of a defined takeover-related event and a fall in the bonds' rating triggered the put. The drafting mode - an affirmative right to resell the bond to the issuer as opposed to a conventional negative covenant - suited the circumstances. A borrower does not necessarily possess the power to prevent a threatened change of control. A covenant thus could be violated unintentionally, with the possible perverse effect of triggering cross defaults on unprotected bonds, bootstrapping their holders and potentially putting the borrower into financial distress. ${ }^{54}$

By 1990, poison put provisions appeared in 40 percent of new investment-grade bonds. Usage thereafter fell off, along with the incidence of high-leverage restructuring. ${ }^{55}$ By the mid-1990s, the clauses appeared in around 25 percent of new bond contracts, with their incidence heavily concentrated in the non-investment-grade segment of the market. ${ }^{56}$ Part 4 will show that these provisions made a notable return after 2000.

\section{Business covenants in practice: risk, return, and market segment}

50716 F. Supp. 1504 (S.D.N.Y. 1989).

51 See Sharon Steel Corp. v. Chase Manhattan Bank, 691 F. 2d 1039, 1049 (2d Cir. 1982).

52 For a discussion of the legal treatment of bondholder-stockholder conflicts, see Bratton, loc. cit. $\mathrm{n}$. 47; M. McDaniel, 'Bondholders and Stockholders', 13 J. Corp. L. (1988) p. 205; L. Mitchell, 'The Fairness Rights of Corporate Bondholders', 65 N.Y.U. L. Rev. (1990) p. 165; M. Riger, 'The Trust Indenture as Bargained Contract: The Persistence of Myth, 16 J. Corp. L. (1991) p. 211; H. Kanda, 'Bondholders and Equityholders', 21 J. Legal Stud. (1992) p. 431.

53 See W. Bratton, 'Venture Capital on the Downside: Preferred Stock and Corporate Control', 100 Mich. L. Rev. (2002) p. 891 at p. 933.

54 Today, a well-drafted cross-default clause will pick up the triggering of a put. See W. Bratton, Corporate Finance: Cases and Materials, 5th edn. (New York, Foundation Press 2003) pp. A-63A-65.

55 See M. Kahan and M. Klausner, 'Anti-Takeover Provisions in Bonds: Bondholder Protection or Management Retrenchment?’ 40 UCLA L. Rev. (1993) p. 931.

56 Nash, Netter, and Poulsen, loc. cit. n. 34, at p. 224 and n. 12. 
Contracting practice has not changed much since bond contracts were adjusted in the wake of the event risk shock. The market has distinct segments - public bonds, bank loans, and private placements. Generally speaking, the public markets are open to larger, safer firms firms with higher credit ratings, higher ratios of fixed assets to total assets, and higher profitability. ${ }^{57}$ Most lending, however, occurs in the two private markets. ${ }^{58}$ Generally speaking, the private placement market, funded by insurers and pension funds, serves the bottom end - the smallest, weakest, worst-rated firms with the highest risk of default. The banks lend to firms in between - medium credit quality firms too small to access the public markets. ${ }^{59}$ Durations vary with the segment - the median maturity is ten years in the public market, 8.2 years in the private placement market and three years for bank borrowings. ${ }^{60}$ The lines between the market segments, while perceptible, are not fixed. Nothing prevents a public bond issuer from borrowing through a private placement if it finds the terms suitable; a large but risky issuer may have access to the public junk bond market. Although the public bond market is reserved for issues registered under the Securities Act of $1933^{61}$ and public issues must be governed by trust indentures conforming to the requirements of the Trust Indenture Act of $1939,{ }^{62}$ private placement issues may be traded over-the-counter in the Rule $144 \mathrm{~A}^{63}$ market, open only to buyers meeting a test of financial substance.

Covenant usage varies across the segments, with incidence tending to follow the borrower's credit rating. Investment-grade bond issuers continue to enjoy only minimal constraint. Junk bond issuers must live with covenants, but at a level of constraint less intense than that accompanying bank borrowing. Both bank loans and private placement loans made to poorer credits imply significant constraints. The intensity of the constraints also varies with the mode of the transaction. Bank loans and private placements tend to involve a small number of lenders who can coordinate renegotiation of the contract terms with the borrower in the event of a covenant default. Coordination in the wake of public bond defaults is more unwieldy and expensive, due to the large number of dispersed holders. This implies looser constraints. ${ }^{64}$

Whatever the lending context, the description of pricing sensitivity and risk-return trading in a costly contracting hypothesis remains robust only in part. One does not see much evidence of the theory's prediction of borrowers trading higher levels of protection for lower yields, or trading higher yields for greater flexibility. Covenant intensity follows default risk. Accordingly, more covenants mean higher yields.

\subsection{Contracting practice and market segment}

A recent study by Michael Bradley and Michael Roberts describes contracting practice in the market for bank loans. Drawing on the Dealscan database, they summarize the terms of 12,425 bank loans made between 1993 and 2001, The sample, which includes 364-day facilities, revolving credit agreements, and term loans, ${ }^{65}$ has an average maturity of 3.5 years.

57 D. Denis and V. Mihov, The Choice Among Bank Debt, Non-Bank Private Debt and Public Debt: Evidence from New Corporate Borrowings, working paper (2002) p. 3, available at: $<$ http://ssrn.com/abstract $=269129>$.

58 Bradley and Roberts, op. cit. n. 36, at p. 8.

59 Ibid., at pp. 3-4.

${ }^{60}$ Ibid., at p. 13.

$61 \quad 15$ U.S.C. $\S \S 77 \mathrm{a}$, et seq.

6215 U.S.C. $\S \S 77$ aaa, et seq.

17 C.F.R. $\S 230.144$ A.

${ }^{64}$ See Smith and Warner, loc. cit. n. 22, at pp. 150-152.

65 Bradley and Roberts, op. cit. n. 36, at pp. 9-11. 
The mean issuer has $\$ 2.5$ billion of assets and, in 2001, the average principal amount was $\$ 318$ million. ${ }^{66}$ Data are collected on six protective provisions: (1) early warning provisions grounded in accounting numbers; (2) security; (3) dividend covenants; (4) asset sweeps (requiring prepayment of the loan in the event of a sale of assets in an amount exceeding a set percentage of the principal amount); (5) debt sweeps (requiring prepayment of the loan in the event of subsequent borrowing exceeding a set percentage of the principal amount); and (6) equity sweeps (requiring prepayment of the loan in the event of a sale of new equity securities in an amount exceeding a set percentage of the principal amount). Table 1 sets out a sample of the results.

Table 1: Covenants in bank loans, 1993-2001

\begin{tabular}{|l|c|c|c|}
\hline Covenant & All years & $\mathbf{1 9 9 3}$ & $\mathbf{2 0 0 1}$ \\
\hline $\begin{array}{l}\text { Number of early } \\
\text { warning covenants }\end{array}$ & 2.52 & 2.13 & 2.52 \\
\hline Security & $77 \%$ & $84 \%$ & $72 \%$ \\
\hline Dividend & $85 \%$ & $82 \%$ & $81 \%$ \\
\hline Asset sweep & $62.5 \%$ & $32 \%$ & $94 \%$ \\
\hline Debt sweep & $46 \%$ & $18 \%$ & $81 \%$ \\
\hline Equity sweep & $46 \%$ & $25 \%$ & $75 \%$ \\
\hline
\end{tabular}

Source: Bradley and Roberts (2004) from Dealscan ${ }^{67}$

We see that substantial protection is the rule - the terms cover claim dilution, asset withdrawal, underinvestment, and asset substitution. We also see a notable shift in the practice. In 1993, sweeps were the exception; by 2001 they had become the rule. The results also imply that a small portion of the loans lacked any covenant protection, and Bradley and Roberts break out these numbers. Four percent of the loans had none of the six provisions in the set; eight percent of the loans had only one.

Shifting over to the bond market implies a reduction in the incidence and intensity of covenants, even for borrowers of the same risk class as the bank borrowers. Stuart Gilson and Jerold Warner demonstrate this, comparing the debt contracts governing twenty-seven firms that issued junk bonds to pay down existing bank loans. ${ }^{68}$ Table 2 sets out some of their findings.

Table 2: Same issuer junk bond and bank loan contracts compared

\begin{tabular}{|l|c|c|}
\hline & Junk bond & Bank loan \\
\hline Investment covenant & $6 \%$ & $97 \%$ \\
\hline Asset sale covenant & $17 \%$ & $92 \%$ \\
\hline $\begin{array}{l}\text { Debt financing (debt covenant, negative pledge and/or } \\
\text { sale/leaseback) }\end{array}$ & $50 \%$ & $98 \%$ \\
\hline
\end{tabular}

${ }^{66}$ Ibid., at p. 10 , table 3.

67 Ibid., table 1.

68 S. Gilson and J. Warner, Private versus Public Debt: Evidence from Firms that Replace Bank Loans with Junk Bonds, working paper (1998), available at: <http://ssrn.com/abstract=140093> (sample covering the period 1980-1991). 


\begin{tabular}{|l|l|l|}
\hline Early warning tests & $33 \%$ & $86 \%$ \\
\hline Dividend covenant & $69 \%$ & $81 \%$ \\
\hline
\end{tabular}

Source: Gilson and Warner (1998) ${ }^{69}$

The shift from the private to the public markets clearly enhances management flexibility, most notably respecting asset management but also respecting financing.

The decrease in the number of early warning covenants reflects a particular borrower objective. Gilson and Warner show that the performance of the firms in the sample tended to decline in the period prior to the shift from the banks to the bond market. Although not distressed, the issuers did face default on the terms of their bank loans, particularly the early warning triggers. The shift to the bond market thus averted the burden of bank loan renegotiation from a position of disadvantage, not only enhancing the issuers' flexibility, but lowering their transaction and monitoring costs. ${ }^{70}$ The banks tend to set their warning trip wires tightly, referencing recent accounting results. Renegotiation in the wake of failure to meet the numbers is a normal event, with the banks resetting the provisions to reflect the real world outcome. ${ }^{71}$ Default declaration and acceleration are not ordinary expedients. With junk bonds, in contrast, such seriatim renegotiations are not feasible. We accordingly can infer that the trip wires in the minority of bond contracts containing them provided a much later early warning than did the bank contracts.

Public bond contracts do indeed hold out considerable borrower flexibility. A sample of public issue bonds collected by Robert Nash, Jeffry Netter and Annette Poulsen provides an instructive comparison with the bank loan data. Nash, Netter and Poulsen went to the public filings to cull 365 bonds issued in 1989 by 259 firms and 398 bonds issued in 1996 by 241 firms. The mean duration of the bond issues is 17.4 years. In 1996, the mean issuer had $\$ 6.7$ billion of assets and the mean loan principal was $\$ 177.7$ million. ${ }^{72}$ Table 3 shows some of the terms governing the issues in the sample.

Table 3: Public bond issues, 1989 and 1996

\begin{tabular}{|c|c|c|c|c|c|}
\hline \multicolumn{1}{|c|}{ Secured } & Junk rating & $\begin{array}{c}\text { Senior (not } \\
\text { subordinated) }\end{array}$ & $\begin{array}{c}\text { Dividend } \\
\text { covenant }\end{array}$ & $\begin{array}{c}\text { Debt } \\
\text { covenant }\end{array}$ \\
\hline 1989 & $24.1 \%$ & $40 \%$ & $66.3 \%$ & $39.7 \%$ & $40 \%$ \\
\hline 1996 & $12.1 \%$ & $25.4 \%$ & $86.2 \%$ & $20.8 \%$ & $27.4 \%$ \\
\hline \multicolumn{7}{|c|}{} \\
\hline 1989 & $\begin{array}{c}\text { Negative } \\
\text { pledge }\end{array}$ & $\begin{array}{c}\text { Sale/lease- } \\
\text { back }\end{array}$ & $\begin{array}{c}\text { Merger } \\
\text { covenant }\end{array}$ & $\begin{array}{c}\text { Poison } \\
\text { put }\end{array}$ & $\begin{array}{c}\text { Asset } \\
\text { sales }\end{array}$ \\
\hline 1996 & $50.1 \%$ & $11.2 \%$ & $66.3 \%$ & $31.6 \%$ & $12.9 \%$ \\
\hline
\end{tabular}

Source: Nash, Netter and Poulsen (2003) ${ }^{73}$

${ }^{69}$ Bradley and Roberts, op. cit. n. 36, table 4.

70 Ibid., at p. 4.

71 See I. Dichev and D. Skinner, 'Large-Sample Evidence on the Debt Covenant Hypothesis', $40 \mathrm{~J}$. Accounting Research (2002) p. 1091.

${ }_{72}$ Nash, Netter, and Poulsen, loc. cit. n. 34, at pp. 208-209, 211-212 and tables 1 and 2.

73 Ibid., tables 2, 3 and 7. 
The decline in the number of secured and subordinated issues reflects a wider trend in the 1990s bond market. The figures on negative pledge and sale/leaseback covenants contradict a conventional wisdom ${ }^{74}$ that these provisions always appear, no matter how highly rated the issuer. Negative pledge and sale/leaseback clauses show up in only one-half and one-tenth of the 1989 bonds, respectively, and merger covenants appear in only two-thirds. Looking at the converse side of this, one-third of the 1989 issues apparently were entirely without covenants. The substantially increased appearance of these covenants in the 1996 bonds signals movement back toward protection. We should not make too much of this, however. The return of the negative pledge and sale/leaseback clauses protects seniority but not other claim dilution. The increased appearance of merger covenants from two-thirds to nine-tenths does not imply protection against high-leverage restructuring or other injurious mergers. As we have seen, the standard covenant only requires that the surviving firm be organized domestically and formally assume the debt, with the latter at all events occurring by operation of law. The standard covenant also covers sales of all or substantially all assets, requiring formal assumption by the purchasing firm. Here the covenant goes farther than the operation of law, but in so doing only makes an asset sale the functional equivalent of a merger. No restrictions on the successor firm's financial condition need be implied, absent debt and dividend covenants. The standard merger covenant thus holds out an important barrier against an extreme form of opportunistic stripping of the asset base from the borrower entity without otherwise significantly inhibiting management's freedom of action. The puzzle concerns not its reappearance but its omission from one-third of the 1989 bonds.

Turning now to debt and dividend covenants, note that the percentages of bonds below investment grade roughly correspond to the percentage of issues containing these covenants, inviting an association between ratings and terms. Nash, Netter, and Poulsen confirm this with a statistical showing. The more restrictive debt and dividend covenants tend to be bundled together and show up in junk issues, the less restrictive negative pledge and sale/leaseback provisions also tend to be bundled together and show up in investment-grade issues. ${ }^{75}$ Other correlations follow suit: bonds with debt and dividend covenants tend to have higher yields, are less likely to be senior, and are more likely to be callable, convertible, and subordinated. The decrease in the appearance of debt and dividend covenants between 1989 and 1996 thus follows from shifts in the credit mix in the sample rather than from shifts in contracting practice. Note that it also follows that some, but not all, of the increase in the appearance of negative pledge and sale/leaseback provisions between 1989 and 1996 stems from differences in the samples.

We can take away a point about covenant protection and credit rating - relatively stronger protection obtains for riskier bonds, but not protection in full. The lower figures for asset sale covenants imply that even many junk bond contracts fall short in their coverage of predictable bondholder-stockholder conflicts, covering asset withdrawal but not asset substitution.

A larger sample of bonds has been collected by Sudheer Chava, Praveen Kumar, and Arthur Warga from the Fixed Income Security Database, which provides information on up to fifty-four different contract terms. The authors collect information on 9,149 debt securities issued between 1980 and 2003 by 3,033 different non-financial firms. ${ }^{76}$ Table 4 presents a selection of the findings.

74 See supra n. 42.

75 Nash, Netter, and Poulsen, loc. cit. n. 34, at p. 219 and table 4.

76 S. Chava, P. Kumar and A. Warga, Agency Costs and the Pricing of Bond Covenants, working paper (2004) pp. 1, 11-12, available at: <http://ssrn.com/abstract=611801>. 
Table 4: Bond issues, ${ }^{77}$ 1989-2003

\begin{tabular}{|c|c|c|c|c|}
\hline & $\begin{array}{c}\text { Dividend } \\
\text { covenant }\end{array}$ & $\begin{array}{c}\text { Restricted } \\
\text { payments }\end{array}$ & $\begin{array}{c}\text { Debt } \\
\text { covenant }\end{array}$ & $\begin{array}{c}\text { Investment } \\
\text { covenant }\end{array}$ \\
\hline $1980-89$ & $27.2 \%$ & $12 \%$ & $13.4 \%$ & $5.6 \%$ \\
\hline $1990-94$ & $19.7 \%$ & $16.7 \%$ & $19.1 \%$ & $5.6 \%$ \\
\hline $1995-99$ & $4.3 \%$ & $23.3 \%$ & $24.4 \%$ & $2.6 \%$ \\
\hline $2000-03$ & $1.0 \%$ & $23.7 \%$ & $13.9 \%$ & $1.7 \%$ \\
\hline & Negative & $\begin{array}{c}\text { Sale/lease- } \\
\text { back }\end{array}$ & $\begin{array}{c}\text { Merger } \\
\text { covenant }\end{array}$ & $\begin{array}{c}\text { Poison } \\
\text { put }\end{array}$ \\
\hline & $25.8 \%$ & $15.4 \%$ & $67.9 \%$ & $19.7 \%$ \\
\hline $1980-89$ & $51.2 \%$ & $32.9 \%$ & $71.2 \%$ & $26.1 \%$ \\
\hline $1990-94$ & $70.5 \%$ & $48.0 \%$ & $89.7 \%$ & $46.4 \%$ \\
\hline $1995-99$ & $67.4 \%$ & $44.7 \%$ & $91.1 \%$ & $96.2 \%$ \\
\hline $2000-03$ & & & & \\
\hline
\end{tabular}

Source: Chava, Kumar, and Warga (2004) from Fixed Income Security Database ${ }^{78}$

This data set fleshes out the evolutionary picture. The first two covenants, 'dividend' and 'restricted payments' cover the same territory - payments by the firm to shareholders whether by dividend or share repurchase. A substantial overlap between the categories safely can be assumed. ${ }^{79}$ Given that assumption, an inference of stability arises - around one-quarter of bond contracts regulate dividends. But which contracts? The authors collect bond ratings for a large subsample, and approximately 30 percent are junk rated, a figure that roughly corresponds with the dividend protected segment. ${ }^{80}$ But this is a tendency not a rule. Table 5 presents a rating by rating breakdown of the issues that include dividend covenants. The results are intuitively satisfying, for incidence shoots up when the bonds turn the corner to junk at 'BA' and continues to increase as creditworthiness deteriorates. But we also are left with two puzzles. Significant numbers of investment-grade issuers also give up this covenant, and the economic literature has not yet taken up the task of accounting for this phenomenon. At the same time, significant numbers of junk bond issuers do not give up the covenant. Here too one looks for an explanation.

Table 5: Dividend covenants by credit rating, 1989-2003

\begin{tabular}{|l|c|c|c|c|c|c|c|}
\hline Rating & AAA & AA & A & BAA & BA & B & CAA \\
\hline Dividend covenant & $5.1 \%$ & $13.1 \%$ & $11.7 \%$ & $9.0 \%$ & $46.9 \%$ & $77.7 \%$ & $80.7 \%$ \\
\hline
\end{tabular}

Source: Chava, Kumar, and Warga (2004) from Fixed Income Security Database and Lehman Bros. Bond Database

77 Although the database includes private placements as well as public bonds, the authors do not specifically identify the bonds as coming from one or the other market. The inference arising from the results is that the sample includes only bonds.

${ }_{78}$ Chava, Kumar, and Warga, op. cit. n. 76, table 2.

79 One suspects unsophisticated or inconsistent coding by the database provider. Note that, depending on the drafting, a restricted payment clause also can contain a restriction on investments.

80 Chava, Kumar, and Warga, op. cit. n. 76, table 6. 
Returning to Table 4, it becomes necessary to qualify the suggestion of a return to protection in the 1990s hypothesized in respect of Nash, Netter and Poulsen's results. While dividend covenants persist in a relatively stable proportion, debt covenants have a volatile pattern and may be in decline. Investment covenants have nearly disappeared. Growth rates in the appearance of negative pledge and sale/leaseback covenants have leveled off. But the merger covenant continues its upward trend and now is close to ubiquitous. Once again, this does not signal substantive movement in the direction of bondholder protection - the puzzle here continues to be the merger covenant's absence from one-third of the 1980s issues.

The most notable data concern poison puts. Recall that their usage peaked at the end of the era of high-leverage restructuring and then fell off. ${ }^{81}$ Bond buyers made a clear-cut risk return decision when choosing between issues with and without this event risk protection. Around 1990, inclusion lowered the average bond yield by 24 basis points. ${ }^{82}$ The price effect grew in magnitude as the bond rating declined - for a BAA bond the spread was 65.7 basis points. ${ }^{83}$ But, because high-leverage restructuring almost disappeared in the early $1990 \mathrm{~s}$, those who bought the higher-yielding, riskier bonds appeared to have made a good deal. Conditions changed later in the decade, however.

Although high-leverage restructuring has not returned to the headlines, it has indeed returned to the markets with the resurgence of private equity transactions. Bondholders seem to have noticed. Although today's private equity financings may implicate lower leverage than did deals in the 1980s, they still combine high leverage and rating downgrades. Downgrades still trigger bond sell-offs. Indeed, increased bond market participation by foreign institutions subject to portfolio constraints aggravates the magnitude of such shocks. ${ }^{84}$ Table 6 presents Mergerstat data on numbers of going private transactions as a percentage of total public company acquisitions. ${ }^{85}$ The growing numbers correlate positively with the change in the bond contracting pattern.

Table 6: Going private transactions as a percentage of public company acquisitions

81 The Chava, Kumar, and Warga data obscure this because the authors group the entire decade of the 1980s together and then break the time sample at 1990, the peak year.

82 I. Crabbe, 'Event Risk: An Analysis of Losses to Bondholders and "Super Poison Put" Bond Covenants', 46 J. Fin. (1991) p. 689.

83 S. Bae and D. Klein, 'Further Evidence on Corporate Bonds with Event-Risk Covenants: Inferences from Standard and Poor's and Moody's Bond Ratings', 37 Q. Rev. Econ. \& Fin. (1997) p. 709 at p. 720. See also K. Cremers, V. Nair, and C. Wei, The Impact of Shareholder Control on Bondholders, NYU Law and Economics Working Paper (2004), available at: $<$ http://ssrn.com/abstract $=516564>$.

84 See M. Whitehorse, 'LBOs May Spoil the Corporate Bond Party', Wall St. J. (1 August 2005) p. $\mathrm{C} 1$.

85 Mergerstat defines 'going private' as an acquisition of a public company by a private investment group or individual where the buyer is not an operating business. Because going private transactions tend to involve smaller firms, the proportion of transactions measured by deal value is lower. 


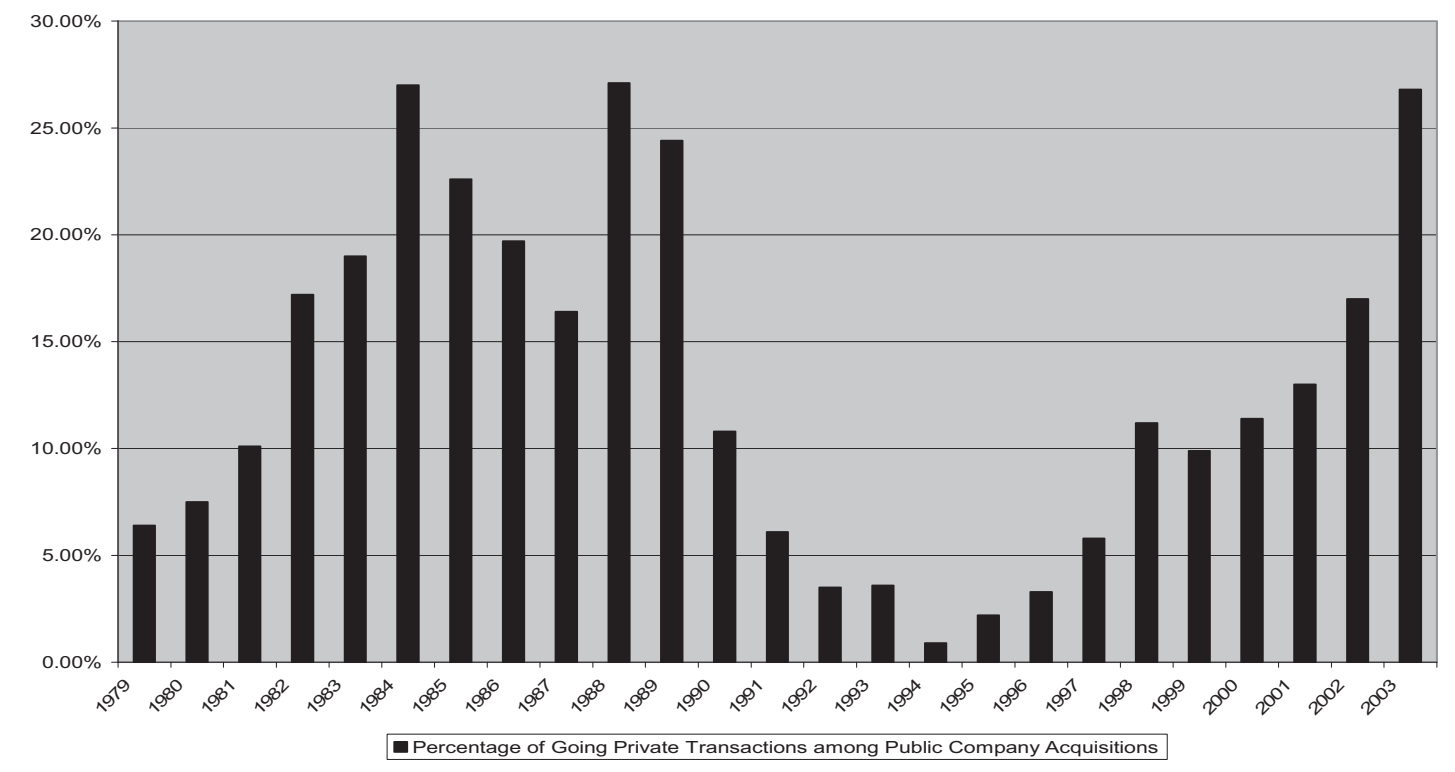

Source: Mergerstat

The almost universal inclusion of poison puts in the most recent generation of bond contracts amounts to the high watermark of the incidence of protective provisions in bond contracts during the past thirty years. As such it presents a bit of a puzzle - why this sudden, pervasive resort to protection in contrast to the limited, selective response of a decade earlier? Issuer indifference seems unlikely, so the change by hypothesis has occurred on the bondholder side. Apparently, aversion to event risk has become more salient. Not only have bond buyers become concerned, they have registered their concern so emphatically with the underwriters as to prompt responsive drafting across the board. The implication is that more is at stake than the rate spread and risk premium - issue marketability seems to be at stake.

\subsection{Covenants, risk, and return}

Bradley and Roberts make a more particular showing of covenant incidence by dividing their bank loan sample based on how many of the six designated covenants appear in each contract. They sort for a range of variables, including (1) the loan spread (here the difference between the interest rate on the loan and the six-month LIBOR rate); (2) the borrower's market-to-book ratio (book liabilities plus market equity to book assets); (3) tangible assets (property plant and equipment over total assets); (4) duration (number of months to maturity); (5) the log of the market capitalization; and (6) leverage (total debt to total assets). Table 7 sets out these figures.

Table 7: Covenants in bank loans and issuer characteristics, 1993-2001

\begin{tabular}{|c|c|c|c|c|c|c|c|}
\hline $\begin{array}{c}\text { Number of } \\
\text { covenants }\end{array}$ & $\begin{array}{c}\text { Percent of } \\
\text { loans in } \\
\text { sample }\end{array}$ & Spread & $\begin{array}{c}\text { Market-to- } \\
\text { book }\end{array}$ & $\begin{array}{c}\text { Tangible } \\
\text { assets }\end{array}$ & $\begin{array}{c}\text { Maturity } \\
\text { (months) }\end{array}$ & $\begin{array}{c}\text { Log } \\
\text { (Market } \\
\text { cap) }\end{array}$ & Leverage \\
\hline 0 & $4 \%$ & 0.43 & 2.22 & $36 \%$ & 45 & 7.80 & $24 \%$ \\
\hline 1 & $8 \%$ & 0.77 & 1.93 & $36 \%$ & 46 & 6.71 & $26 \%$ \\
\hline 2 & $13 \%$ & 1.82 & 1.83 & $36 \%$ & 42 & 5.36 & $31 \%$ \\
\hline 3 & $14 \%$ & 2.10 & 1.69 & $33 \%$ & 44 & 5.19 & $36 \%$ \\
\hline
\end{tabular}




\begin{tabular}{|l|l|l|l|l|l|l|l|}
\hline 4 & $12 \%$ & 2.18 & 1.89 & $33 \%$ & 56 & 5.73 & $40 \%$ \\
\hline 5 & $19 \%$ & 2.41 & 1.69 & $29 \%$ & 60 & 5.36 & $39 \%$ \\
\hline 6 & $30 \%$ & 2.69 & 1.65 & $30 \%$ & 63 & 5.38 & $42 \%$ \\
\hline
\end{tabular}

Source: Bradley and Roberts (2004) from Dealscan ${ }^{86}$

The numbers are intuitively satisfying. The least protected loans, those with zero or one covenant, constitute only twelve percent of the sample. These loans have notably lower interest rates, and involve borrowers with higher market capitalization, more tangible assets, and lower leverage. They also are larger firms - the log of market capitalization serves as a proxy for size, and shows that the least protected loans involve materially larger borrowers. Apparently, the large firms bargain for a zone of flexibility roughly approximating that available in the bond market.

As the number of covenants increases so do the interest rate, the time to maturity, and the borrower's leverage. At the same time, more lender protection means a lower market-to-book ratio and fewer tangible assets. More generally, covenant protection increases linearly with the risk of the loan. Nash, Netter and Poulsen reach a similar result respecting the differential appearance in their sample of debt and dividend covenants and negative pledge and sale/leaseback covenants. The latter, lesser protection package corresponds with lower yields. $^{87}$

The strong positive correlation between covenants and yields traverses the costly contracting hypothesis. The hypothesis predicts a negative relationship between covenant intensity and yield - the issuer offers the covenants and lower agency costs in exchange for a lower cost of borrowing, much as we saw with the pricing of poison puts. The bank loan data and the hypothesis can be read together nonetheless. The parties do not make risk return trade-offs in the form of a choice between minimal and full protection across the range of borrower risk levels. The small, risky borrower is not positioned to bargain for a high interest loan under a convenantless contract. At the same time, large borrowers do not appear inclined to surrender their flexibility in exchange for a rock-bottom coupon. With a given risk class, there appears to be some trading room. Bradley and Roberts, testing for yield sensitivity to the presence or absence of a given covenant, find that the yield does decrease in the presence of four of the six covenants. ${ }^{88}$

\subsection{Covenants, growth firms, and investment policy}

Recent studies of bond covenants focus heavily on Stewart Myers' thirty-year-old hypothesis concerning underinvestment. Myers, viewing the equity as the holder of an option to repurchase the firm from the debt, posited the underinvestment problem: where the option remains out of the money, net of the proceeds of a given positive NPV investment on the date the debt matures, the equity has no reason to make the investment. He suggested that the dividend covenant serves as a partial palliative, by locking capital in the firm; he noted in addition that shorter maturities also reduce the tendency. ${ }^{89}$ Since then, economists have expanded Myers' point into a prediction that the underinvestment problem will be particularly salient in respect of growth firms. From there they go on to look for a correlation between growth firms and dividend constraints.

86 Bradley and Roberts, op. cit. n. 36, table 6.

87 Nash, Netter, and Poulsen, loc. cit. n. 34, at p. 219 and table 4.

88 Bradley and Roberts, op. cit. n. 36, table 8.

89 Myers, loc. cit. n. 23, at pp. 159-161. 
The option perspective gives rise to a second prediction about growth firms. Their equity, as option holders, also will want to reserve flexibility to make all feasible positive NPV investments so as to maximize the chance that the option expires in the money. ${ }^{90}$ The prediction is that growth companies will preserve their investment flexibility by preserving concomitant financing flexibility, thus avoiding debt covenants. The two predictions coexist in tension, one predicting overinvestment and the other underinvestment. But they can be read together - the flexibility concern arises on the side of a borrower projecting good times, while the underinvestment concern arises on the side of a lender projecting bad times.

A third prediction respecting growth firms comes from Michael Barclay and Clifford Smith. Under this prediction, firms with growth opportunities can be expected to finance with secured debt and capital leases so as to reduce the likelihood that gains will be shared with existing unsecured debt claimants; incentives to underinvest thereby will be minimized. Growth firms thus can be expected to draft their contracts so as to reserve room for such high priority financing. ${ }^{91}$ Presumably, this means that they resist negative pledge clauses and sale/leaseback constraints.

Tests of these predictions, employing the market-to-book ratio as a proxy for a growth orientation, tend to confirm the flexibility prediction and negate the dividend covenant and secured borrowing predictions. The results of Nash, Netter and Poulsen, set out in Table 8, reflect the trend. ${ }^{92}$ They arbitrarily break their sample into a binary set of 'high growth' and 'low growth' firms; all results are statistically significant. Bradley and Roberts get the same association respecting future financing flexibility. But they also show a weaker positive correlation between growth and dividend constraints, and growth and secured status. ${ }^{93}$

Table 8: Growth firms

\begin{tabular}{|l|c|c|}
\hline & High growth & Low growth \\
\hline Dividend covenant & $11.3 \%$ & $28.5 \%$ \\
\hline Debt covenant & $15.0 \%$ & $33.3 \%$ \\
\hline Negative pledge & $72.5 \%$ & $62.6 \%$ \\
\hline Sale/leaseback & $44.5 \%$ & $35.7 \%$ \\
\hline
\end{tabular}

Source: Nash, Netter and Poulsen (2003)

The confirmation of the flexibility prediction is unsurprising - the borrower's interest in flexibility has driven contracting practice in the bond market for decades. The Bradley and Roberts results associating growth firms, dividend constraints, and underinvestment call for a more cautious interpretation. Credit quality determines the covenant pattern in both the public and private markets. When a dividend covenant appears, it accompanies a poor credit and more likely reflects the lender's fear of asset withdrawal than fear of underinvestment. Indeed, assuming separation of ownership and control, it is unclear whether underinvestment is particularly likely to be a problem - the managers have every reason to continue to invest

90 Nash, Netter, and Poulsen, loc. cit. n. 34, at p. 205.

91 M. Barclay and C. Smith, 'The Priority Structure of Corporate Liabilities', 50 J. Fin. (1995) p. 899 at p. 907.

92 See also M. Kahan and D. Yermack, 'Investment Opportunities and the Design of Debt Securities', 14 J. L. Econ. \& Org. (1998) p. 136 (showing that growth firms tend toward covenantless convertible bond contracts); Chava, Kumar, and Warga, op. cit. n. 76, at pp. 14-16.

93 Bradley and Roberts, op. cit. n. 36, at p. 27 and table 8.

94 Nash, Netter, and Poulsen, loc. cit. n. 34, at p. 219 and table 4. 
in order to move the firm away from distress and hold on to their jobs whether or not the equity's option is expected to expire in the money. When negative pledge clauses show up, they serve as a minimal constraint that protects the lender's priority position in the capital structure of a good credit, a firm unlikely to be forced to borrow on a secured basis. Finally, the short maturities of the bank loans analyzed by Bradley and Roberts suggest that underinvestment is unlikely to determine contractual choices.

\subsection{Summary and analysis}

We noted at the outset that the agency costs of debt are the costs of financial distress. That point goes a long way toward explaining contracting practice in US credit markets. Covenants linearly follow the probability of distress. The best credits for the most part avoid their inclusion, preserving their freedom of action. Lesser credits must include them, with the intensity of lender protection increasing as creditworthiness declines.

While levels of contractual protection clearly impact the price of credit, there is relatively little of the trading of price and protection predicted by the costly contracting hypothesis. The market does not hold out a complex menu of risk-return combinations. Investment-grade credits do not offer full sets of covenants in order to minimize their cost of borrowing. Poor credits do not get the opportunity to preserve their flexibility by offering a premium price. A highly risk-averse bondholder does not get the opportunity to select a super safe portfolio of investment-grade bonds, the issuers of which all have contractually minimized possible agency costs. This bondholder instead is remitted to the ordinary expedients of portfolio diversification and hedges in the derivatives market. ${ }^{95}$ Bond insurance, a normal recourse in the municipal bonds markets, provides an alternative recourse for a only small subset of bonds. $^{96}$

The explanatory power of the linear link between risk, return, and contract protection is not absolute, however. Anomalies abound. We do not yet know why some investment-grade credits have had the option to issue covenantless bonds when other similarly situated firms offer minimal protection. Nor do we know why still other investment-grade issuers offer more than minimal protection. Nor do we have an explanation for the market's steadily shifting reactions to the risks of mergers, asset sales, and leveraged restructurings. Long a persistent and puzzling area of underprotection, these agency costs now prompt a protective response across the board. The costly contracting hypothesis may or may not provide cogent answers to these open questions. Where covenants are absent, free riding also holds out an explanation - perhaps the missing protections can be found in other debt contracts in the borrower's capital structure. ${ }^{97}$ Even so, explanatory recourse to the murkier world of path dependencies, intermediary preferences, and investor behavioral shortcomings ultimately may prove necessary.

\section{Process barriers}

95 Credit derivatives are now available for larger issuers on an intermediate term basis. See R. Blanco, S. Brennan and I. Marsh, 'An Empirical Analysis of the Dynamic Relationship of Investment Grade Bonds and Credit Default Swaps', 60 J. Fin. (2005) p. 2255 at pp. 2257-2262.

96 See S. Davydenko, The Role of Debt Insurance, working paper (2003), available at: $<$ http://phd.london.edu/SDavydenko/DebtInsurance.pdf $>$. The market concentrates on utility issues rated AA to BBB with 74 percent of the contracts covering A issues. Dealers and retail investors take out the contracts.

97 Lenders thus relying assume significant risks. Nothing prevents the borrower from paying down the better-protected loan. In a distress situation, the better-protected lender may get an opportunity to negotiate concessions from the borrower while the unprotected lender must sit on its hands. 
Although corporate debt contracts hold out a only a short menu of risk-return combinations and have yet to be explained fully in a number of respects, it has been many years since anyone has contended that the practice holds out significant adverse selection problems. Such a claim was voiced in the $1980 \mathrm{~s}$, when the contracts' failure to protect against event risk surprised many bond market participants. ${ }^{98}$ But the point lost salience a few years later when actors in the bond markets proved willing to assume event risk in exchange for a premium ranging from 25 to 60 basis points. Today, complaints about bond contracts concern process rather than substance, in particular the mechanisms that order processes of renegotiation surrounding default.

\subsection{Amendments and waivers}

We have seen that covenants in public bond issues tend to be less tightly drafted than covenants in bank loans and private placements, even respecting borrowers of comparable credit standing. The stricter the covenants the more likely the need for amendment or waiver in the event the borrower's performance deteriorates. With publicly traded bonds, the amendment process is both cumbersome and expensive. Debt contracts, both public and private, typically permit covenants to be amended or waived by a majority (simple or twothirds of principal amount) of the holders thereunder. ${ }^{99}$ Given a large number of holders, this means a formal proxy solicitation, usually made on a take-it-or-leave-it basis without negotiation. Such dispersed bondholders, like shareholders, can suffer the classic collective action problem. The trust indenture device does nothing to alleviate the problem because it imposes no duty on the indenture trustee to represent the bondholders in connection with contract renegotiations. Institutional holding ameliorates the problem, however. Large bondholders can identify and contact one another and sometimes organize. They also have been known to reject issuer proposals. ${ }^{100}$ Such uncooperative behavior is unsurprising -

98 See the authorities cited supra at n. 52.

99 For a formal, incomplete contracts model of bond contract amendment, see N. Gareanu and J. Zwiebel, Design and Renegotiation of Covenants, working paper (2005), available at: $<$ http://ssrn.com/abstract $=470780>$.

${ }^{100}$ See M. Kahan and B. Tuckman, 'Do Bondholders Lose from Junk Bond Covenant Changes?', 66 J. Bus. (1993) p. 499. This presents the results of a study of 58 consent solicitations in which an issuer of widely held debt requested the modification of existing covenants but did not request either interest deferral or principal forgiveness. Nearly all of the issues surveyed were junk bonds. The solicitations broke down as follows: 25 were simple consent solicitations in which receipt of an offered cash payment was conditioned on consent to the amendment; 24 were accompanied by tender offers; eight were accompanied by exchange offers; one was accompanied by a tender offer and an exchange offer. A requirement of an exit consent or consent as a condition to payment was present in 44 of the 48 offers for which data could be found. The issuers sought, inter alia, to make leveraged acquisitions ( 31 percent), make dividends or other stockholder payments (13.8 percent), conduct recapitalizations ( 10.3 percent), sell assets ( 8.6 percent), and issue more debt ( 6.9 percent). The average payment offered in those solicitations exchanging the consent for cash was $\$ 20.51$ per $\$ 1,000$ face value; the median cash payment was $\$ 15$ per $\$ 1,000$ face value; nine of the 23 cash offers were above $\$ 20$; the two largest were $\$ 60$ and $\$ 95$. Evidence of the result of the solicitation was found for 52 of the cases, and in 83 percent of these the solicitation succeeded. Kahan and Tuckman conclude that the issuers have not been exploiting the structural opportunity to coerce that the bond contracts create. They hypothesize that the bondholders can, in practice, coordinate their response so as to insure an adequate level of payment. As evidence, they cite the formation of bondholder groups in twelve cases; of these twelve solicitations, eleven either failed or had their 
bondholders, unlike institutional lenders, have no interest in a reputation for cooperation. It follows, at the bottom line, that issuers must induce bondholder consents with cash. All of this stiffens the borrower's ex ante resistance to the inclusion of covenants.

Thus do process frictions appear to impose an opportunity cost on substantive protections. This leads Yakov Amihud, Kenneth Garbade, and Marcel Kahan to propose an alternative process regime. ${ }^{101}$ Under their proposal, bond contracts would designate a 'super trustee' empowered to negotiate covenant amendments. With a designated negotiator, they assert, covenants would not hold out deadweight process costs on downside scenarios, permitting tighter, more effective covenants to appear in publicly traded issues. They note that this change could be accomplished on a strictly contractual basis.

The proposal assumes that, but for the process barriers, the costly contracting hypothesis would operate so that borrowers would find it in their interest to include more restrictive terms. While the assumption undoubtedly is correct at some level, the evidence presented in the preceding sections prompts questions respecting the scope of the risk-return trading zone opened thereby. Investment-grade issuers might welcome a smoother process regime, but are unlikely to follow up with substantive concessions inhibiting their freedom of action. We have seen that the best credits evade covenants even when borrowing from banks. As the authors emphasize, room for trade more likely opens in the junk bond market, where a protection differential obtains between private loans and public bonds. Borrower incentives still present a question. To the extent managers highly value the flexibility opened by relaxed covenants, they could prove willing to leave money on the table in the form of higher borrowing costs. Given separation of ownership and control, bargaining over debt contracts does not occur at the financial margin, and the agency costs of equity could influence the result. Looking to the other side of the bargaining table, there is no reason to assume that, but for the process barriers, underwriters would follow the same contracting path as the agents of banks. For the underwriters, present marketability matters more than long-term performance. Meanwhile many bond buyers can be expected to continue to trade contract protection for liquidity and present yield.

\subsection{Payment terms, exchange offers, and unanimous action}

Now consider deeper distress situations, where default in the payment of interest or principal has become a present possibility. Here bankruptcy reorganization looms as an expensive and risky alternative for both borrowers and bondholders. Both may be better off if the borrower and its lenders can agree to a composition: the lenders agree to a scale-down of their claims to interest and principal either because the projected cost savings of avoided bankruptcy exceed the value of the rights surrendered, or, failing that, because the borrower adds a sweetener - for example, a present payment of principal from the proceeds of the sale of a piece of its business.

With bank loans and private placements, the lenders customarily coordinate and negotiate with the borrower face to face. Process problems once again prevent that with issues of bonds. Moreover, the bond contract interposes an additional process barrier. While providing for amendment of covenants by a majority assent, it requires unanimous bondholder assent to amend or waive a payment term. The unanimity rule is mandated under the Trust Indenture

terms modified before approval. Over all, in 42 percent of the cases, the issuers modified the terms after an initial failure to obtain consents.

${ }^{101}$ Y. Amihud, K. Garbade and M. Kahan, 'A New Governance Structure for Corporate Bonds', 51 Stan. L. Rev. (1999) p. 447. 
Act for publicly issued bonds. ${ }^{102}$ Although the mandate does not cover private placement and bank loans, unanimous action requirements respecting payment terms remain the universal practice respecting corporate lending in the United States. ${ }^{103}$ As a practical matter, the unanimous action requirement makes direct amendment of a bond payment term impossible outside of Chapter 11 of the Bankruptcy Code, which interposes a majoritarian voting regime. ${ }^{104}$

Unanimous action provisions do not, however, present an absolute bar to debt restructuring outside of bankruptcy. A composition can be effected by indirection. Instead of being asked to vote on an amendment of their bond contracts, the bondholders are asked to exchange their bonds for substitute bonds that contain modified terms more favorable to the borrower. The borrower neither expects nor requests universal participation. But the bargaining posture is problematic. Consider the game posited in Table 9.

Table 9: Exchange offer game

\begin{tabular}{|c|c|c|c|}
\hline & & Bondholder B & \\
\hline & & Cooperate & Defect \\
\hline Bondholder A & Cooperate & 625,625 & $\underline{550}, 800$ \\
\hline & Defect & $\underline{800}, 550$ & 400,400 \\
\hline
\end{tabular}

The set-up assumes that a borrower in distress has offered its two bondholders a composition featuring substitute bonds worth 550 . The bondholders cannot identify one another. The offer is stingy: if the bondholders could surmount their collective action problem and negotiate with the borrower, they can get the offer increased to 625 . Under the offered terms, either or both bondholders can accept; obviously, the composition fails if both refuse. In that case, the borrower goes into bankruptcy where the projected recovery is 400 , yielded after a long lapse of time.

On these facts, holding out, 'defecting' in the parlance of game theory, can mean an 800 payoff. One but not both of the bondholders can maximize on this free riding strategy. To reject an exchange offer is to hold on to your bond. The holder thereby retains the borrower's original promise to pay and all other contract rights, even as the exchanging holders make concessions in respect of the timing and amount of payments. If the offer succeeds, the holdout is 'buoyed up', benefiting from the borrowers' emergence from distress and economic recovery along with the holder who exchanges, but having made no concessions. Here, if both bondholders follow this strategy, the exchange offer fails and borrower goes into bankruptcy.

Given the set-up, it is unclear what each bondholder should do. The underlined outcomes in Table 9 show A's optimal moves given the alternatives of cooperation and defection by B. If $\mathrm{B}$ accepts the offer, $\mathrm{A}$ is better holding out and taking the 800 . But if $\mathrm{B}$ holds out, $\mathrm{A}$ is

102 Trust Indenture Act of 1939, § 316, 15 U.S.C. $\S 77 \mathrm{ppp}$ (also providing for a delay of payment of interest of up to three years based on a 75 percent vote). M.J. Roe, 'The Voting Prohibition in Bond Workouts', 97 Yale L. J. (1987) p. 232 at p. 234, shows that the purpose of the section was to discourage out of court compositions so as to force the parties into the then new Chapter $\mathrm{X}$ bankruptcy procedure, where strong judicial supervision was provided for. Roe argues, correctly, that subsequent changes in bankruptcy law and practice remove the need for the mandate. Ibid., at p. 316.

${ }^{103}$ H. Kashner, 'Minority Clauses and Non-Bankruptcy Corporate Reorganizations - Contractual and Statutory Alternatives', 44 Bus. Law. (1988) p. 123 at pp. 124-125.

${ }^{104} 11$ U.S.C. § 1129(a). 
better off cooperating and taking the 550, thereby avoiding the worst case payoff of 400 . Since A does not know what B is going to do, it is not clear how A should play. This situation is unstable; this is a multiple equilibrium game. ${ }^{105}$

Real world corporate exchange offers can present similarly difficult choices. They tend to be made on a take-it-or-leave-it basis, absent prior negotiation. They also tend to be structured to succeed only if the number of holdouts is small: supermajority acceptance generally is required - something more than 80 percent - to minimize the siphoning of value to holdouts. Meanwhile, specialized hedge funds, known as 'vulture funds', specialize in such strategic behavior. They purchase the bonds on the secondary market after the onset of distress at a deep discount and then play non-cooperatively. ${ }^{106}$ This aggravates the risk of failure: if the subsidy to the holdouts is greater than the increase in value to the exchanging creditors, every one is better off refusing to exchange. ${ }^{107}$ The failure of the offer, of course, leaves everybody worse off.

If the borrower in the above example fears the offer will fail, whether because of the holdout problem or because the bondholders will refuse to cooperate because they believe the borrower can afford a package worth 625 , it can heighten the stakes and set up a coercive exchange. It now offers 550 in the form of new debt that is secured by property to which the holders of the original bonds would look for payment in bankruptcy. Nothing prevents this if the bond contract lacks a negative pledge clause. Holding out now carries additional risk. The holdout retains the original bond with its promise to pay the original amount, but the bond is junior to the new bonds issued in the exchange. The change in status reduces the value of the holdout's bonds to below 800 . How low the value goes depends on the numbers. In a real world case where 90 percent of the bondholders accept the offer, the security soaks up most of the value of the firm, pushing the value of the holdout bonds well below 550. Absent coordination, the bondholders may be forced to take the bad deal. Note that here the holdout possibility arguably benefits the group as whole. ${ }^{108}$

The borrower can coerce the bondholders even if the bond contract contains a negative pledge. It structures an 'exit consent'. This combines the exchange offer with a proposal to amend the bond contract to remove the negative pledge, which like all terms other than payment terms is subject to majority amendment. The cooperative, exchanging bondholders vote in favor of the amendment even as they exit by sending in their old bonds for exchange. This leaves the holdouts with their original principal and interest terms intact but subject to diminution in value due to the senior status of the new bonds. ${ }^{109}$ The courts have approved the exit consent device in the face of challenges under the contract law duty of good faith. ${ }^{110}$

Bond contracts easily can be drafted to block these coercive exchanges, indeed to block all exchanges. The issuer simply promises not to make any exchange offers. So long as that promise can be amended only by unanimous consent, any exchange offer is an event of default. This strategy is followed in private placement contracts ${ }^{111}$ but not public bond indentures. ${ }^{112}$ But revision of the bond drafting practice to follow the private placement

${ }^{105}$ In a standard prisoners' dilemma set-up, defection is optimal for both A and B and there is only one equilibrium.

${ }^{106}$ J. Coffee, Jr. and W. Klein, 'Bondholder Coercion: The Problem of Constrained Choice in Debt Tender Offers and Recapitalizations', 58 U. Chi. L. Rev. (1991) p. 1207 at pp. 1207-1214.

${ }^{107}$ Roe, loc. cit. n. 102, at p. 236.

${ }^{108}$ Coffee and Klein, loc. cit. n. 106, at p. 1223.

${ }^{109}$ On the use of exit consents to engineer sovereign debt restructurings, see L. Buchheit and G. Gulati, 'Exit Consents in Sovereign Bond Exchanges', 48 UCLA L. Rev. (2000) p. 59.

${ }^{110}$ See Katz. v. Oak Industries Inc., 508 A. 2d 873 (Del. Ch. 1986).

${ }^{111}$ See Bratton, loc. cit. n. 54, at pp. A-54-A-55, A-70 $(\S \S 8.5,17)$.

112 Revised Model Simplified Indenture, 55 Bus. Law. (2000) p. 1115 (Article 9). 
approach is not necessarily desirable. Private placement lenders can effect compositions despite the exchange offer prohibition - small numbers make unanimous consent feasible, and relational concerns among repeat players minimize holdout problems. With public bonds, a strict unanimity regime would as a practical matter foreclose the option of out of bankruptcy composition.

\subsection{Process reform in distress situations}

Two routes to the amelioration of process problems inhibiting voluntary compositions by highly distressed issuers can be suggested - a greater and a lesser. The greater is a super trustee arrangement, such as that suggested by Amihud, Garbade, and Kahan. Here, as is not the case with simple covenant defaults, the Trust Indenture Act would have to be amended to permit the arrangement. The question would go to the magnitude of the delegation to the trustee - either of a full power to bind the bondholders to a payment amendment or of a power to negotiate subject to a ratifying vote. An analogy to process in Chapter 11 suggests that only the latter approach would be acceptable to the lending community. Inside the Chapter, claimants surrender negotiating power to class representatives but vote on the composition on a majoritarian basis. The lesser route is a simple amendment of the Trust Indenture Act to permit amendment of payment terms by majority (or super majority) vote.

As between the two alternatives, trustee negotiation followed by ratification holds out clear-cut advantages. Majoritarian voting opens up the possibility of side payments from the borrower to selected members of the group of lenders. A borrower, for example, can offer a preferred position in a future lending group or other business advantages in exchange for support of a composition that extracts value from a minority creditor group. Under a unanimity regime, even the suggestion of inequality across the creditor group can trigger a 'no' vote; majority rule opens up room for wheeling and dealing. The interposition of a negotiating fiduciary reduces this risk in addition to facilitating face-to-face dealing.

Reform, whether in the greater or lesser version, holds out advantages. Despite this, support from the US lending community cannot be safely assumed. Nothing has prevented the inclusion of majoritarian amendment clauses in bank loans, private placements, and sovereign debt contracts, but such innovations have been resisted. Sovereign debt contracts have shifted to a majoritarian approach in recent years, but only as a result of political pressure placed on sovereign borrowers by the US Treasury Department. ${ }^{113}$

Why do bondholders continue to resist the logic of collective action, which otherwise pervasively shapes corporate institutional arrangements? Myopia, path dependence, and the rest of the list of evolutionary barriers can be suggested. It also should be noted that the zone of private contractual choice for a unanimity regime overlaps the zone of institutional lending. With banks and private placement lenders, relational constraints minimize the holdout problem. But none of this satisfactorily answers the question. If the bondholder community thought that the Trust Indenture Act's unanimity mandate sacrificed substantial value, it easily could lobby to procure the Act's amendment.

It accordingly is worth considering the possibility that lenders perceive financial advantages in a unanimous consent regime. Consider a formal model of bondholding and bond voting structures articulated by Patrick Bolton and David Scharfstein. ${ }^{114}$ This suggests that a low-quality firm would find it optimal to maximize its liquidation value: a distress

${ }^{113}$ See S. Choi and M. Gulati, 'Innovation in Boilerplate Contracts: An Empirical Examination of Sovereign Bonds', 53 Emory L.J. (2004) p. 927.

${ }^{114}$ P. Bolton and D. Scharfstein, 'Optimal Debt Structure and the Number of Creditors', $104 \mathrm{~J}$. Pol. Econ. (1996) p. 1. 
default being likely, it would want contracts carrying as little cost as possible in the event of default. The smaller the number of creditors and the lower the voting barrier, the cheaper the liquidation and the greater the value of the debt. ${ }^{115}$ A high-quality firm, in contrast, presents little risk of a distress default. Here Bolton and Scharfstein see strategic default as the dominant problem - for example, the borrower might default on a covenant because it voluntarily seeks to shift value to its equity. Factors increasing the cost of such a default such as multiple creditors and tougher voting rules - enhance the value of the debt. ${ }^{116} \mathrm{We}$ emerge with a trade-off keyed to the borrower's credit quality. But Bolton and Scharfstein go on to make an additional suggestion that operates across the board: the greater the number of creditors and the higher the percentage of bondholder votes needed to approve a composition renegotiation, the lower the borrower's surplus in the renegotiation. ${ }^{117}$ This point says something important about lenders' preference for unanimous action: although lender dispersion disfavors enforcement when the burden to act lies on the lenders' side (due to small stakes and free-rider problems ${ }^{118}$ ), when the tables turn and the borrower must obtain the lenders' assent, a high numerical threshold can be advantageous. ${ }^{119}$

Of course, the holdout problem complicates the analysis. But a hard-nosed bondholder has a response: if the offer makes a generous split of a surplus, holdouts will not be so numerous as to threaten the deal. No one ever expects 100 percent participation in a composition, yet such exchange offers close all the time on the basis of supermajority acceptance. A look at the leading private case, Katz v. Oak Industries, ${ }^{120}$ shows a complex exchange offer with an upset participation requirement of 85 percent. That upset calculation will change from situation to situation. Meanwhile, there is no evidence that holdouts regularly cause exchange offers to fail. ${ }^{121}$ When offers fail, it may be that they are too low and as a result attract something much less than a supermajority of creditors. ${ }^{122}$

A numerical example helps explain this. Assume a distressed borrower whose bonds are trading for 650, a value that can be expected to fall further unless a composition succeeds. The borrower, already on the road to recovery, can afford to pay 950 . The total bonded indebtedness is 1,000 . The surplus is 950 minus 650 or 300. Let us assume that under a twothirds majority amendment provision, the borrower can get the requisite participation by offering a bond worth 750 in exchange - a two-thirds to one-third split of the surplus in the borrower's favor. With a unanimous action provision, it will have to offer more in order to satisfy higher upset prices among the remaining bondholders. Assume that if it offers a bond worth 850, it will get 90 percent participation under a unanimous action bond contract, leaving holdouts with face value claims of 1,000 . The value of the 850 exchange offer is as follows:

$$
850 \times .90=765
$$

${ }^{115}$ Ibid., at p. 3.

${ }^{116}$ Ibid.

117 Ibid., at p. 18. See also A. Bris and I. Welch, 'The Optimal Concentration of Creditors', 60 J. Fin. (2005) p. 2193 (summarizing the literature making this point).

${ }^{118}$ See B. Holmstrom, 'Moral Hazard in Teams', 13 Bell J. Econ. (1982) p. 324.

${ }^{119}$ Bris and Welch, loc. cit. n. 117, at 2193-94.

${ }^{120} 508$ A.2d 873 (Del. Ch. 1986).

${ }^{121}$ S. Gilson, 'Transactions Costs and Capital Structure Choice: Evidence from Financially Distressed Firms', 52 J. Fin. (1997) p. 161, shows that the holdout problem does not seem to be so severe as to prevent the accomplishment of restructurings respecting public debt, particularly given use of coercive devices like exit consents. See also J. Helwege, 'How Long Do Junk Bonds Spend in Default?' 54 J. Fin. (1999) p. 341.

${ }^{122}$ See Kahan and Tuckman, loc. cit. n. 100. 
$1,000 \times .10=\underline{100}$

865 - total yield to the bondholders

This recovery reverses the percentage division of the surplus - now it is roughly two-thirds to the bondholders and one-third to the borrower. The problem lies in the possibility that too many bondholders will hold out and defeat the offer, leaving the holders with bonds worth 650. Let us assume that composition failures due to holdouts are rare - a 20 percent possibility. The question is whether that possibility makes the offer under the two-thirds majority clause more attractive. It does not:

$865 \times .80=692$

$650 \times .20=\underline{130}$

$822>750$

Now say the probabilities are 50-50:

$865 \times .50=432.50$

$650 \times .50=\underline{325}$

$757.50>750$

The expected value of the offer under the unanimity clause is still greater than that of the offer under the majority amendment clause. Only at under a 50-50 chance of success does the majority amendment clause create value for the bondholders as a whole.

These numbers are posed for the sake of argument. To the extent they strike the reader as plausible, unanimity requirements are not irrational, and value creation under majority rule is not a sure thing. Process reform to improve the out of bankruptcy composition process accordingly is a low probability event.

The extension of the Chapter 11 reorganization process into the territory of pre-bankruptcy composition reinforces the presumption favoring the status quo. The Bankruptcy Code allows a distressed corporate debtor to compose a reorganization plan and solicit consents before making a formal bankruptcy filing. ${ }^{123}$ The filing occurs after the consents have been collected, following the Bankruptcy Code's majoritarian process rule. Such a 'prepackaged' plan of reorganization then is presented to the bankruptcy court for quick confirmation. This alternative now predominates over contractual compositions because it holds out tax advantages for the borrower. Process protections, albeit minimal, also are implicated.

\subsection{Summary and analysis}

The bondholder collective action problem raises two questions. The first concerns the problem's effect ex post: whether distressed issuers, through coercively structured, take-it-orleave-it offers, succeed in effecting compositions more favorable than could be obtained in an arm's length negotiation with an effectively represented lender. The second question concerns the problem's effect ex ante: whether, but for the incremental costs of ex post renegotiation, public bond contracts would contain protective covenants comparable to those included in bank loans and private placements.

To answer both questions in the affirmative is to support investing the indenture trustee with the powers of a negotiating agent. To realize such a reform's full potential, the trustee-

${ }^{123} 11$ U.S.C. $\$ 1126(b)$. 
agent would need power to negotiate both amendments and waivers of payment terms as well as amendments and waivers of covenants. This could be done on an experimental basis by amending the Trust Indenture Act to include an 'opt in' permission. Specifically, the Act could provide that a qualified indenture could permit amendments and waivers presenting payment terms on a majoritarian basis, provided that the indenture also invested the trustee with negotiating power and, in the case of a payment term, also required bondholder ratification of the trustee's composition. The 'opt in' approach has the advantage of letting the market decide whether it prefers the traditional unanimous consent approach to structured negotiation and majority consent. Note that the proposal omits the requirement of bondholder ratification where the amendment or waiver concerns a covenant rather than a payment term. The reason lies in problem of ex ante effects. The negotiating trustee device holds out the potential ex ante benefit of encouraging borrowers to include tighter covenants only if the trustee's decision respecting covenant recontracting is final and the expense and uncertainty of bondholder ratification is avoided.

To answer the first question in the negative is to rely on self-protection by institutional bondholders. Such reliance is more reasonable today than at any time in bond market history. Vulture funds do not hesitate to raise their voices, to vote 'no' on consent solicitations, and even to bring lawsuits. Indeed, they are so uncooperative and obstreperous in their pursuit of maximal settlements from distressed borrowers as to suggest a negative answer to the second question. Borrowers already looking to the bond market for loans on easy terms will be disinclined toward change. The prospect of dealing with empowered trustees constrained by worries about the reactions of vulture investors will not further entice them. Underwriters who now market trust indentures containing generally-phrased terms from the contract form

file will move toward more protective contracting only if the bond market registers emphatic demands. The market recently appears to have registered such demands on event risk. Whether it would take the occasion of process reform to go farther and insist on more effective protection respecting problems like claim dilution, asset withdrawal, and asset substitution is an open question.

\section{Conclusion}

This article undertook a review of corporate debt contracting practice in the United States toward the end of gauging the appropriate scope of the contractual reproach to creditor protection in positive law. It now concludes that the scope of the reproach lies in the eye of the beholder.

This article's analysis offers much to suit an observer inclined to the view that the institution of contract provides a robust and complete framework for creditor protection. The practice respecting corporate borrowing has been remarkably stable, much more so than, say, the positive law framework governing shareholder-manager relations. At the same time, the practice has proved responsive to external shocks, whether by redrafting, by repricing, or both, as occurred with event risk. Nor does the account hold out a point at which regulatory intervention clearly would push the practice in a more efficient direction. When bondholders injured by opportunistic managers and shareholders took their complaints to court in the 1980s only to be remitted back to the contracting table, the market took the matter in its stride. That it finally opted for protection against event risk after a decade's lapse bespeaks a contractual success. Finally, however provocative may be the case made for bond market process reform, nothing suggests that the market demands it - if stronger trustees add significant value to bond contracts, we would have seen them long ago.

An observer inclined to be suspicious about the robustness and completeness of contractual creditor protections can reverse this reading. Although contract law assumes that 
corporate debt contracts are complete, the practice shows otherwise. The market works effectively only with small numbers of lenders who have reputational incentives not to exploit borrowers who get into difficulty ex post. Rational borrowers enter into compete contracts ex ante only when the circumstances assure them of that zone for ex post renegotiation. Where the assurance is lacking, as with public bonds, contracts seemingly tend to be incomplete. That the contracts price out the resulting risks does not prove the optimality of the substantive allocation. Indeed, the bond markets for the most part deal with the agency cost problem not through considered contractual risk allocation but through crude appraisal based on the borrower's credit standing. Meanwhile, agency problems and transaction costs prevent the evolution of a superior contract form. The market's puzzling treatment of event risk supports these assertions. Finally, there is a favorable implication for the positive law of creditor protection: when the financial markets see a high agency cost risk, they either procure contractual protection or refuse to lend. This implies a function for positive law in contexts less suited to considered rejection of risky borrowers. 